\title{
Mineralogy and geochemistry of Asian dust: dependence on migration path, fractionation, and reactions with polluted air
}

\author{
Gi Young Jeong \\ Department of Earth and Environmental Sciences, Andong National University, Andong 36729, Republic of Korea
}

Correspondence: Gi Young Jeong (jearth@anu.ac.kr)

Received: 16 October 2019 - Discussion started: 16 January 2020

Revised: 27 March 2020 - Accepted: 12 May 2020 - Published: 26 June 2020

\begin{abstract}
Mineralogical and geochemical data are essential for estimating the effects of long-range transport of Asian dust on the atmosphere, biosphere, cryosphere, and pedosphere. However, consistent long-term data sets of dust samples are rare. This study analyzed 25 samples collected during 14 Asian dust events occurring between 2005 and 2018 on the Korean Peninsula and compared them to 34 soil samples $(<20 \mu \mathrm{m})$ obtained from the Mongolian Gobi Desert, which is a major source of Asian dust. The mineralogical and geochemical characteristics of Asian dust were consistent with those of fine source soils in general. In dust, clay minerals were most abundant, followed by quartz, plagioclase, $\mathrm{K}$-feldspar, calcite, and gypsum. The trace element contents were influenced by the mixing of dust with polluted air and the fractionation of rare earth elements. Time-series analyses of the geochemical data of dust, combined with satellite remote sensing images, showed a significant increase in the $\mathrm{Ca}$ content in the dust crossing the Chinese Loess Plateau and the sandy deserts of northern China. Calcareous sediments in the sandy deserts and pedogenic calcite-rich loess are probable sources of additional Ca. Dust-laden air migrating toward Korea mixes with polluted air over East Asia. Gypsum, a minor mineral in source soils, was formed by the reaction between calcite and pollutants. This study describes not only the representative properties of Asian dust but also their variation according to the migration path, fractionation, and atmospheric reactions.
\end{abstract}

\section{Introduction}

Mineral dust blown from arid lands is transported to remote atmospheric, terrestrial, cryogenic, and marine environments, contributing to the circulation of earth materials (Martin and Fitzwater, 1988; Dentener et al., 1996; Biscaye et al., 1997; Jickells et al., 2005; Mahowald and Kiehl, 2003; Zdanowicz et al., 2007; Formenti et al., 2011; Jeong et al., 2013, 2014; Serno et al., 2014). Asia is one of the major sources of mineral dust that are the subject of ongoing interdisciplinary research. The mineral grains of dust interact with atmospheric gases and pollutants (Dentener et al., 1996; Krueger et al., 2004; Laskin et al., 2005; Matsuki et al., 2005), which affects the bioavailability of inorganic micronutrients in remote ecosystems (Meskhidze et al., 2005; Takahashi et al., 2011). The interaction of dust particles with solar and Earth radiation influences the regional energy balance (Forster et al., 2007). The long-term deposition of dust particles on the Loess Plateau, the North Pacific Ocean, and Arctic ice sheets provides a record of paleoclimatic changes (Liu, 1988; An et al., 1991; Porter, 2001; Pettke et al., 2000; Bory et al., 2002; Hyeong et al., 2005; Jeong et al., 2008, 2011, 2013). Asian dust transported over long distances is an important constituent of some soils in Korea and Japan (Bautista-Tulin and Inoue, 1997; Jo et al., 2019). Iron-bearing dust transported to remote oceans has received much attention for its possible role in phytoplankton bloom and carbon dioxide levels (Jickells et al., 2005; Johnson and Meskhidze, 2013). The mineralogical and geochemical analysis of dust extracted from the pelagic sediments of the North Pacific has provided a basis for determining sediment provenance and paleoenvironmental changes (Olivarez et al., 1991; Nakai et al., 1993; Leinen et al., 1994; Rea, 1994; Rea et al., 
1998; Pettke et al., 2000; Hyeong et al., 2005; Serno et al., 2014).

The mineralogical and geochemical properties of bulk samples provide a basis for interdisciplinary research on long-range transported Asian dust. The Earth system models involving Asian dust could be improved by adopting reliable data on dust properties. However, the bulk properties of Asian dust are poorly known due to the application of widely varying analytical procedures and sample weights that are typically very low and, thus, usually insufficient for analysis (Leinen et al., 1994; Kanayama et al., 2002; Shi et al., 2005; Zdanowicz et al., 2007; Jeong, 2008; Jeong et al., 2014). Furthermore, the analyses of scattered sample sets with a limited number of samples make it difficult to detect long-term variation in dust properties. Thus, long-term data sets obtained using consistent analytical methods could provide not only the general mineralogical and geochemical properties of Asian dust for Earth system modeling, but they could also give insight into changes in dust sources, migration paths, and chemical interactions. However, no such data have been reported to date. Mineralogical and geochemical data for Asian dust should be compared to equivalent data for the fine silt fraction in the source soils in order to investigate any fractionation and reaction during long-range transport. The currently available mineralogical and geochemical data for source soils (Biscaye et al., 1997; Honda et al., 2004; Chen et al., 2007; Jeong, 2008; Maher et al., 2009; Ferrat et al., 2011; McGee et al., 2016) are insufficient; mineralogical data are particularly rare.

The purpose of this study is to determine the mineralogical and geochemical properties of bulk dust samples collected over 14 years and compare them to equivalent data for source soils. Variations in the mineralogical and geochemical characteristics are discussed in relation to the migration path, fractionation, and the interaction of Asian dust with atmospheric pollutants.

\section{Samples}

\subsection{Asian dust}

\subsubsection{Outbreak and migration of dust storms}

The outbreak and migration of dust storms crossing the Korean Peninsula were investigated for 14 Asian dust events using an aerosol index derived from data obtained by the Communication, Ocean, and Meteorological Satellite (COMS), which was launched on 27 June 2010 (National Meteorological Satellite Center, 2019). Pre-2011 dust events were tracked using the Infrared Difference Dust Index derived from data obtained by the Multi-functional Transport Satellite1R (MTSAT-1R; National Meteorological Satellite Center, 2019). Data for the 2005 dust events were not available. Four satellite images were selected from the serial image set (1-
$0.5 \mathrm{~h}$ intervals) of each dust event to show (1) the extent of the dust outbreak (i.e., the point where the dust storm reached its maximum size without notable migration), (2) dust migration toward the Korean Peninsula, (3) dust crossing the Korean Peninsula, and (4) dust leaving Korean Peninsula toward the North Pacific Ocean. The dust region identified from the dust index images was drawn on a geographic map including the Gobi Desert, the sandy deserts of northern China, and the Loess Plateau. The outbreak and migration of each dust storm identified from satellite images are provided in Fig. S1 in the Supplement. Figure 1 is a summary of the outbreak and migration of all of the dust storms. The outbreak of dust storms was concentrated in the Gobi Desert and sandy deserts encompassing southern Mongolia and northern China (Fig. 1a). The 2013 dust storm occurred on the Loess Plateau as well as deserts (Fig. S1). The dust storm migrated eastward and southeastward (Fig. 1b). The migration routes of dust storms toward the Korean Peninsula can be divided into two groups: (1) those crossing the Loess Plateau and (2) those making a detour around the north of Loess Plateau. Six dust storms (D3-6, D7, D10-11, D12, D19-20, and D21-23 in Table 1) crossed the Loess Plateau (Fig. S1). Dust-laden air parcels passing the Korean Peninsula were dispersed and diluted progressively, and migrated eastward and northeastward toward the North Pacific Ocean (Fig. 1cd).

\subsubsection{Size distribution}

The volume size distribution was measured with an optical particle counter (OPC; Model 180 GRIMM Aerosol Technik) at the dust monitoring station nearest to the sampling site operated by the Korea Meteorological Administration (2019). The OPC reported particle numbers over 31 size bins from 0.25 to more than $32 \mu \mathrm{m}$. Sample air was directly fed into the measuring cell at a volume flow of $1.2 \mathrm{~L} \mathrm{~min}^{-1}$ by passing it through a total suspended particulate (TSP) head. OPC data for the pre-2010 dust events were not available. The volume size distributions revealed that the modal volume diameters of most dusts were between 2 and $5 \mu \mathrm{m}$ with an average size of $4.6 \mu \mathrm{m}$ (Fig. 2). The volume size distribution of very coarse dust for a 2012 dust event showed an almost monotonic increase toward larger sizes (Jeong et al., 2014). Zdanowicz et al. (2007) reported a modal volume diameter of $4 \mu \mathrm{m}$ for Asian dust that was transported long distances in April 2001 (to the Yukon Territory, Canada); larger particles $(>10 \mu \mathrm{m})$ were also found, indicating rapid transPacific transport in the mid-troposphere. Serno et al. (2014) reported a particle-size mode of around $4 \mu \mathrm{m}$ for eolian dust separated from the deep-sea sediments of the subarctic North Pacific Ocean. 
Table 1. List of Asian dust sampled in Korea and desert soils from the Mongolian Gobi Desert. (All time references in the table refer to Korea standard time, KST.)

\begin{tabular}{|c|c|c|c|c|c|c|c|c|c|}
\hline \multicolumn{7}{|c|}{ Asian dust } & \multicolumn{3}{|c|}{ Mongolian Gobi Desert soil } \\
\hline Sample & Site $^{1}$ & Year & $\begin{array}{l}\text { Date (in dd/mm) } \\
\text { (sampling hour, KST) }\end{array}$ & $\begin{array}{r}\operatorname{Tran}^{2} \\
\text { (h) }\end{array}$ & $\begin{array}{r}\text { Dist. }^{3} \\
(\mathrm{~km})\end{array}$ & $\begin{array}{c}\text { Conc. }^{4} \\
\left(\mu \mathrm{g} \mathrm{m}^{-3}\right)\end{array}$ & Sample & Latitude & Longitude \\
\hline D1 & $\mathrm{AD}$ & 2005 & 20/4 (09:00-17:00) & - & - & 366 & G1 & $45^{\circ} 19^{\prime} 21.39^{\prime \prime} \mathrm{N}$ & $106^{\circ} 32^{\prime} 47.40^{\prime \prime} \mathrm{E}$ \\
\hline D2 & $\mathrm{AD}$ & 2008 & 31/5 (08:00-18:00) & 54 & 1800 & 292 & $\mathrm{G} 2$ & $44^{\circ} 40^{\prime} 39.67^{\prime \prime} \mathrm{N}$ & $106^{\circ} 56^{\prime} 13.41^{\prime \prime} \mathrm{E}$ \\
\hline D3 & $\mathrm{AD}$ & 2009 & 16/3 (09:00-18:00) & \multirow{4}{*}{45} & \multirow{4}{*}{1900} & \multirow{4}{*}{428} & G3 & $44^{\circ} 26^{\prime} 46.20^{\prime \prime} \mathrm{N}$ & $107^{\circ} 08^{\prime} 21.72^{\prime \prime} \mathrm{E}$ \\
\hline D4 & $\mathrm{AD}$ & 2009 & $16 / 3(18: 00)-17 / 3(09: 00)$ & & & & G4 & $44^{\circ} 14^{\prime} 17.02^{\prime \prime} \mathrm{N}$ & $107^{\circ} 32^{\prime} 07.85^{\prime \prime} \mathrm{E}$ \\
\hline D5 & $\mathrm{AD}$ & 2009 & 17/3 (09:00-18:00) & & & & G5 & $44^{\circ} 04^{\prime} 00.11^{\prime \prime} \mathrm{N}$ & $107^{\circ} 43^{\prime} 32.88^{\prime \prime} \mathrm{E}$ \\
\hline D6 & $\mathrm{AD}$ & 2009 & $17 / 3(19: 00)-18 / 3(09: 00)$ & & & & G6 & $44^{\circ} 04^{\prime} 01.97^{\prime \prime} \mathrm{N}$ & $108^{\circ} 16^{\prime} 22.73^{\prime \prime} \mathrm{E}$ \\
\hline D7 & $\mathrm{AD}$ & 2010 & 20/3 (19:00)-21/3 (10:00) & 30 & 2200 & 1788 & G7 & $43^{\circ} 37^{\prime} 48.48^{\prime \prime} \mathrm{N}$ & $108^{\circ} 33^{\prime} 42.42^{\prime \prime} \mathrm{E}$ \\
\hline D8 & $\mathrm{AD}$ & 2011 & 1/5 (09:00-18:00) & 41 & 1300 & 300 & G8 & $43^{\circ} 27^{\prime} 28.00^{\prime \prime} \mathrm{N}$ & $109^{\circ} 01^{\prime} 39.26^{\prime \prime} \mathrm{E}$ \\
\hline D9 & $\mathrm{AD}$ & 2011 & $12 / 5(20: 00)-13 / 5(11: 00)$ & 49 & 1700 & 322 & G9 & $43^{\circ} 14^{\prime} 50.26^{\prime \prime} \mathrm{N}$ & $108^{\circ} 10^{\prime} 02.68^{\prime \prime} \mathrm{E}$ \\
\hline D10 & SL & 2012 & 31/3 (09:00)-1/4 (08:00) & \multirow{2}{*}{25} & \multirow{2}{*}{1700} & 215 & G10 & $43^{\circ} 11^{\prime} 28.31^{\prime \prime} \mathrm{N}$ & $107^{\circ} 01^{\prime} 11.78^{\prime \prime} \mathrm{E}$ \\
\hline D11 & DL & 2012 & 31/3 (09:00)-1/4 (08:00) & & & 220 & G11 & $42^{\circ} 38^{\prime} 16.75^{\prime \prime} \mathrm{N}$ & $107^{\circ} 18^{\prime} 45.96^{\prime \prime} \mathrm{E}$ \\
\hline D12 & SL & 2013 & 9/3 (09:00)-10/3 (08:00) & - & 1500 & 215 & G12 & $42^{\circ} 32^{\prime} 24.88^{\prime \prime} \mathrm{N}$ & $106^{\circ} 55^{\prime} 27.65^{\prime \prime} \mathrm{E}$ \\
\hline D13 & $\mathrm{AD}$ & 2014 & 18/3 (10:00-22:00) & \multirow{2}{*}{42} & \multirow{2}{*}{1800} & 378 & G13 & $42^{\circ} 32^{\prime} 41.71^{\prime \prime} \mathrm{N}$ & $106^{\circ} 29^{\prime} 27.33^{\prime \prime} \mathrm{E}$ \\
\hline D14 & DL & 2014 & 18/3 (09:00-24:00) & & & 214 & G14 & $42^{\circ} 28^{\prime} 43.44^{\prime \prime} \mathrm{N}$ & $106^{\circ} 02^{\prime} 20.82^{\prime \prime} \mathrm{E}$ \\
\hline D15 & SL & 2015 & $22 / 2(09: 00)-23 / 2(08: 00)$ & \multirow{3}{*}{23} & \multirow{3}{*}{1400} & 1044 & G15 & $42^{\circ} 43^{\prime} 57.89^{\prime \prime} \mathrm{N}$ & $105^{\circ} 28^{\prime} 30.02^{\prime \prime} \mathrm{E}$ \\
\hline D16 & $\mathrm{AD}$ & 2015 & $22 / 2(16: 00)-23 / 2(18: 00)$ & & & 469 & G16 & $43^{\circ} 06^{\prime} 27.97^{\prime \prime} \mathrm{N}$ & $104^{\circ} 58^{\prime} 05.30^{\prime \prime} \mathrm{E}$ \\
\hline D17 & DL & 2015 & $22 / 2(09: 00)-23 / 2(08: 00)$ & & & 1037 & G17 & $43^{\circ} 05^{\prime} 29.85^{\prime \prime} \mathrm{N}$ & $104^{\circ} 13^{\prime} 29.36^{\prime \prime} \mathrm{E}$ \\
\hline D18 & $\mathrm{AD}$ & 2015 & $1 / 3(17: 00)-2 / 3(11: 00)$ & 29 & 1600 & 281 & G18 & $42^{\circ} 51^{\prime} 36.78^{\prime \prime} \mathrm{N}$ & $104^{\circ} 08^{\prime} 24.24^{\prime \prime} \mathrm{E}$ \\
\hline D19 & SL & 2016 & $6 / 3(09: 00)-7 / 3(08: 00)$ & \multirow{2}{*}{44} & \multirow{2}{*}{1700} & \multirow{2}{*}{168} & G19 & $42^{\circ} 31^{\prime} 21.33^{\prime \prime} \mathrm{N}$ & $103^{\circ} 51^{\prime} 15.57^{\prime \prime} \mathrm{E}$ \\
\hline D20 & SL & 2016 & 7/3 (09:00)-8/3 (08:00) & & & & G20 & $42^{\circ} 43^{\prime} 41.69^{\prime \prime} \mathrm{N}$ & $103^{\circ} 45^{\prime} 58.64^{\prime \prime} \mathrm{E}$ \\
\hline $\mathrm{D} 21$ & $\mathrm{AD}$ & 2017 & $6 / 5(13: 00-21: 00)$ & \multirow{3}{*}{60} & \multirow{3}{*}{1700} & \multirow{3}{*}{331} & $\mathrm{G} 21$ & $42^{\circ} 52^{\prime} 35.91^{\prime \prime} \mathrm{N}$ & $103^{\circ} 46^{\prime} 44.04^{\prime \prime} \mathrm{E}$ \\
\hline D22 & $\mathrm{AD}$ & 2017 & $6 / 5(21: 00)-7 / 5$ (19:00) & & & & $\mathrm{G} 22$ & $43^{\circ} 10^{\prime} 52.04^{\prime \prime} \mathrm{N}$ & $104^{\circ} 00^{\prime} 38.56^{\prime \prime} \mathrm{E}$ \\
\hline D23 & $\mathrm{AD}$ & 2017 & 8/5 (14:00)-9/5 (10:00) & & & & G23 & $43^{\circ} 21^{\prime} 00.20^{\prime \prime} \mathrm{N}$ & $103^{\circ} 34^{\prime} 18.01^{\prime \prime} \mathrm{E}$ \\
\hline D24 & $\mathrm{AD}$ & 2018 & $6 / 4(15: 00)-7 / 4(09: 00)$ & 47 & 2400 & 194 & G24 & $43^{\circ} 10^{\prime} 55.20^{\prime \prime} \mathrm{N}$ & $103^{\circ} 07^{\prime} 34.28^{\prime \prime} \mathrm{E}$ \\
\hline \multirow[t]{10}{*}{$\mathrm{D} 25$} & $\mathrm{AD}$ & 2018 & $15 / 4(15: 00)-16 / 4(10: 00)$ & 43 & 1300 & 316 & G25 & $42^{\circ} 56^{\prime} 04.51^{\prime \prime} \mathrm{N}$ & $102^{\circ} 01^{\prime} 39.43^{\prime \prime} \mathrm{E}$ \\
\hline & & & & & & & G26 & $42^{\circ} 56^{\prime} 43.06^{\prime \prime} \mathrm{N}$ & $101^{\circ} 39^{\prime} 04.13^{\prime \prime} \mathrm{E}$ \\
\hline & & & & & & & G27 & $43^{\circ} 06^{\prime} 51.96^{\prime \prime} \mathrm{N}$ & $101^{\circ} 04^{\prime} 28.67^{\prime \prime} \mathrm{E}$ \\
\hline & & & & & & & G28 & $43^{\circ} 18^{\prime} 38.66^{\prime \prime} \mathrm{N}$ & $101^{\circ} 05^{\prime} 31.79^{\prime \prime} \mathrm{E}$ \\
\hline & & & & & & & G29 & $43^{\circ} 26^{\prime} 55.40^{\prime \prime} \mathrm{N}$ & $101^{\circ} 15^{\prime} 28.02^{\prime \prime} \mathrm{E}$ \\
\hline & & & & & & & G30 & $43^{\circ} 56^{\prime} 49.43^{\prime \prime} \mathrm{N}$ & $101^{\circ} 27^{\prime} 19.13^{\prime \prime} \mathrm{E}$ \\
\hline & & & & & & & G31 & $44^{\circ} 02^{\prime} 09.93^{\prime \prime} \mathrm{N}$ & $101^{\circ} 30^{\prime} 26.83^{\prime \prime} \mathrm{E}$ \\
\hline & & & & & & & G32 & $44^{\circ} 25^{\prime} 27.10^{\prime \prime} \mathrm{N}$ & $101^{\circ} 33^{\prime} 49.81^{\prime \prime} \mathrm{E}$ \\
\hline & & & & & & & G33 & $44^{\circ} 41^{\prime} 36.96^{\prime \prime} \mathrm{N}$ & $101^{\circ} 52^{\prime} 59.77^{\prime \prime} \mathrm{E}$ \\
\hline & & & & & & & G34 & $45^{\circ} 05^{\prime} 25.65^{\prime \prime} \mathrm{N}$ & $102^{\circ} 18^{\prime} 03.50^{\prime \prime} \mathrm{E}$ \\
\hline
\end{tabular}


(a)

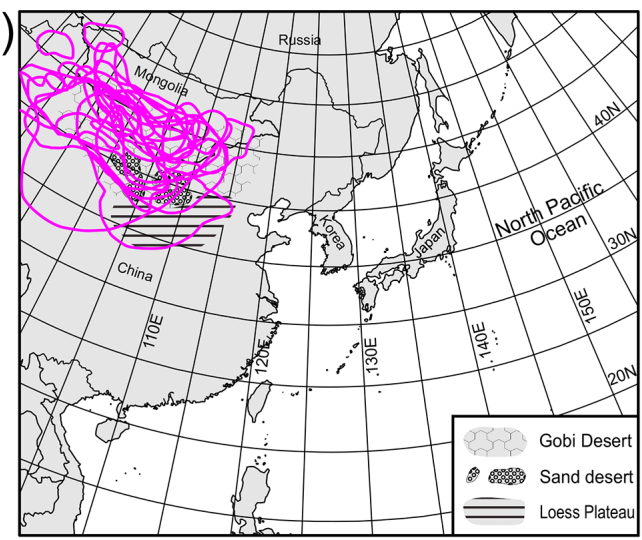

(c)

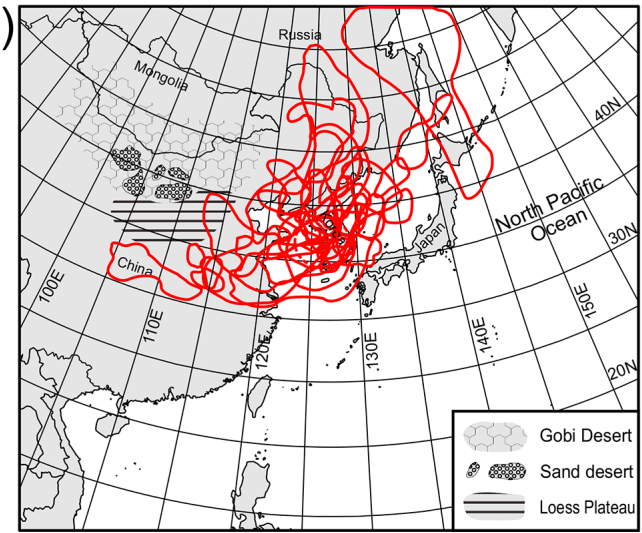

(b)

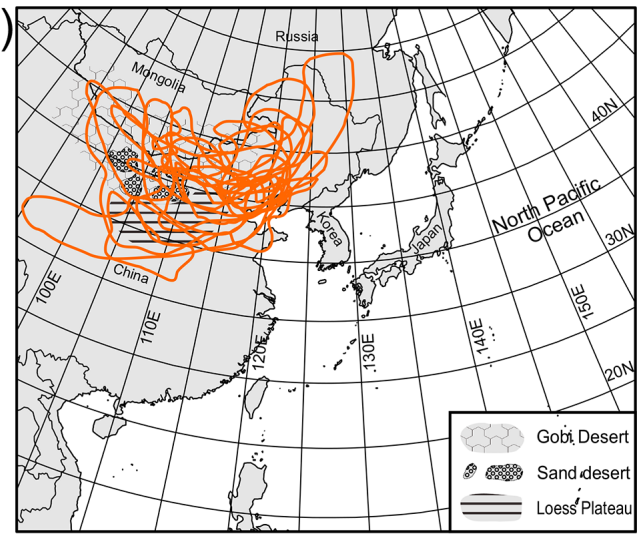

(d)

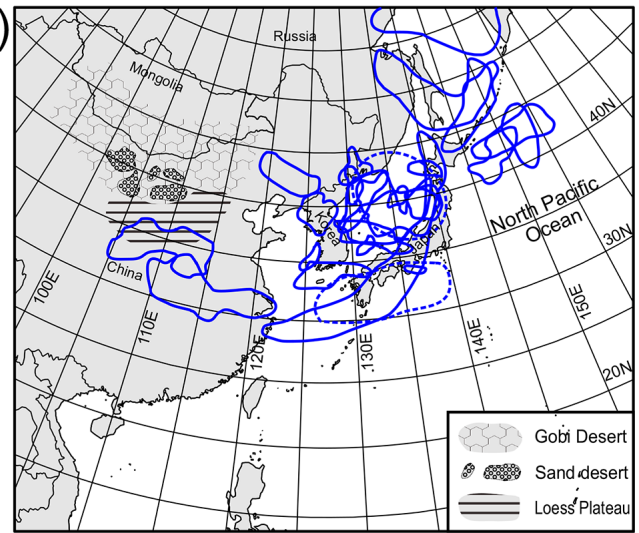

Figure 1. Dust storm outbreaks and migrations during 14 Asian dust events identified from the remote sensing images obtained from the Communication, Ocean, and Meteorological Satellite (COMS; 2011-2018) and the Multi-functional Transport Satellite-1R (MTSAT-1R; 2008-2010). The outbreak and migration path data for individual dust events are provided in Fig. S1. (a) The maximum extent of the dust event during the storm outbreak. (b) Migration of dusty air toward the Korean Peninsula. (c) Dusty air crossing the Korean Peninsula. (d) Migration of dusty air toward the North Pacific Ocean.

\subsubsection{Sampling}

A total of 25 Asian dust samples were collected from 2005 to 2018 at three sites, including Deokjeok Island off the western coast of Korea, Andong National University in Andong, and the Korea Institute of Science and Technology in Seoul (Fig. 3, Table 1). Dust particles were collected on Whatman 1441-866 cellulose filter paper using Tisch Environmental and Thermo Scientific high-volume total suspended particulate (TSP) samplers installed on building rooftops. Jeong (2008) reported on the mineralogical properties of eight dust samples collected during a 3-year period (20032005). However, his samples were collected using $\mathrm{PM}_{10}$ samplers; these exclude coarse particles, which are an important component of some dust events (Jeong et al., 2014). For some events, dust samples were collected at three sites, whereas the samples for other events were collected at one or two sites, depending on the dust migration path. For short (a few hours in duration) events one sample was collected, while 2-4 time series of samples were collected at one site during longer (several days in duration) events. The miner- alogical properties of three TSP samples reported by Jeong et al. (2014) were reanalyzed to ensure consistency in the analytical procedures.

\subsection{Source soils}

The 34 surface soils were sampled in the Mongolian Gobi Desert along a $1700 \mathrm{~km}$ long track in the region between ca. $100-109^{\circ} \mathrm{E}$ and $42-46^{\circ} \mathrm{N}$ (Fig. 3, Table 1). The surface soils of the Gobi Desert are not dominated by the sands typical of sandy desert and are instead characterized by a mixture of pebbles, sand, silt, and clays, although sand dunes are locally distributed. The bare ground, comprising loose silty soils with sparse vegetation and the dry beds of ephemeral lakes, promotes the outbreak of dust plumes under strong winds caused by cold front systems or by a strong pressure gradient at the surface (Chun et al., 2001). About $1 \mathrm{~kg}$ of soil, comprising numerous samples, was taken from the surface after coarse pebbles were removed. All of the soil samples were in the naturally dry state at the sampling time. 


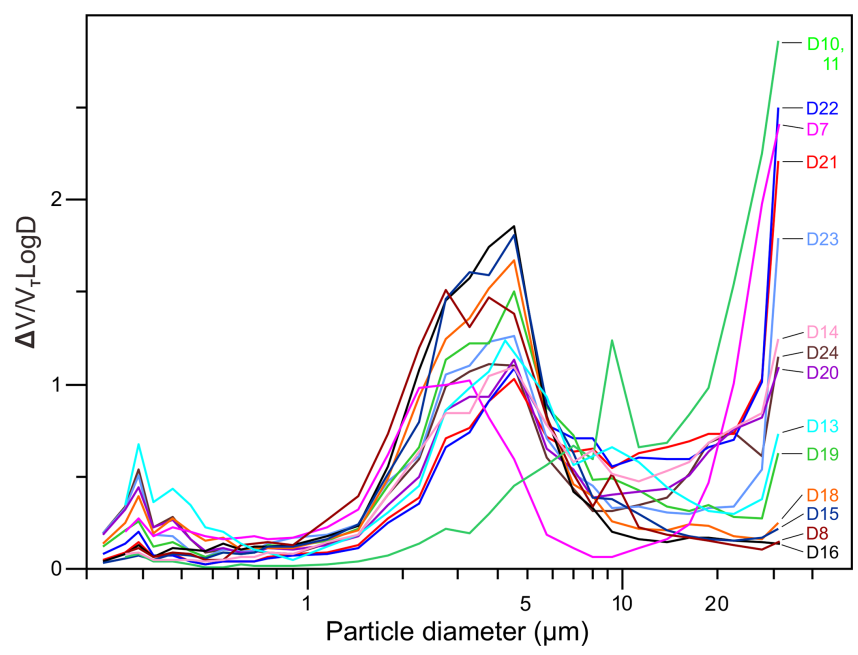

Figure 2. Volume size distributions of aerosols during the Asian dust events, as measured by an optical particle counter located at the nearest Korea Meteorological Administration (KMA) monitoring stations. See Table 1 for the sampling site and time during the dust events.

\section{Analytical methods}

\subsection{Sample preparation}

The cellulose filter papers were shredded into several pieces, each approximately $3 \times 5 \mathrm{~cm}^{2}$ in size, and subjected to ultrasonic agitation, in methanol in a $250 \mathrm{~mL}$ glass beaker, to detach dust particles from the filter. Cellulose fibers were removed from the dust suspension by passing it through a 270 mesh sieve. The dust suspension was dried on a clean glass plate and then collected with a razor blade for X-ray diffraction (XRD) and chemical analysis. Soil samples were passed through a clean $2 \mathrm{~mm}$ sieve to remove pebbles. The $2 \mathrm{~mm}$ fraction soil was sieved under dry conditions through a disposable nylon $20 \mu \mathrm{m}$ sieve, using a Retsch sieve shaker. A total of $2 \mathrm{~g}$ of the soil separate $(<20 \mu \mathrm{m})$ was mixed with ethanol and ground using a McCrone micronizing mill for 7 min with zirconia grinding elements. The dust samples were not ground for XRD analyses to avoid mass loss during the milling, because the dust samples were very small $(<300 \mathrm{mg})$ and were already fine enough for XRD analyses. However, one sample collected during the coarse dust event was ground in an agate mortar.

\subsection{XRD analyses}

Since the weight of the dust samples was insufficient for conventional XRD analysis, XRD data were collected over a long time period $(\sim 12 \mathrm{~h})$. Dust powders were loaded onto a small cavity $\left(\sim 7 \times 20 \mathrm{~mm}^{2}\right)$ in a silicon plate for XRD analysis by side packing to minimize preferred orientation of mineral grains (Moore and Reynolds, 1997). The XRD analyses were performed using a Rigaku Ultima IV diffractome- ter at the Center for Scientific Instruments, Andong National University. The analytical conditions were as follows: counting time, $20 \mathrm{~s}$ per $0.03^{\circ}$ step; $2 \theta, 3-65^{\circ}$; divergent slit, $2 / 3^{\circ}$; scatter slit, $2 / 3^{\circ}$; receiving slit, $0.15 \mathrm{~mm}$; and $\mathrm{Cu} \mathrm{K} \alpha$ radiation, $40 \mathrm{kV} / 30 \mathrm{~mA}$. The counting time was doubled for the samples of very low weight. Given their higher weight, the soil powders were loaded on the $20 \times 20 \mathrm{~mm}^{2}$ cavity by side packing and analyzed at a scan speed of $0.25^{\circ} \mathrm{min}^{-1}$. Mineral identification based on the XRD patterns was carried out using the DIFFRAC.SUITE EVA software (Bruker AXS).

A total of 12 minerals (quartz, plagioclase, K-feldspar, illite, illite-smectite mixed layers, chlorite, kaolinite, amphibole, calcite, dolomite, gypsum, and halite) were quantified using Siroquant software (Sietronics Ltd.) with application of the Rietveld refinement technique. Background subtraction was performed carefully because samples enriched with poorly crystalline clay minerals have high and unresolvable broad diffraction bands, particularly in the range of $20-40^{\circ} 2 \theta$. The low angle region $\left(3-10^{\circ}\right)$ was excluded from the refinement. After the initial refinement, the cell parameters of chlorite, K-feldspar, albite, and calcite were refined to achieve the best fit between the observed and calculated XRD patterns. Although smectite is present as a clay mineral in source soils and dust (Jeong et al., 2008; Park and Jeong, 2016), the XRD patterns of randomly oriented bulk samples are not adequate to distinguish small amounts of smectite from illite-smectite mixed-layer minerals. The refinement often showed that low-crystallinity illite is difficult to reliably distinguish from illite-smectite mixed-layer minerals in dust. This was confirmed by transmission electron microscopy analysis of clay minerals (Jeong and Nousiainen, 2014; Jeong and Achterberg, 2014) and single-particle analysis using scanning electron microcopy (SEM; Jeong et al., 2016). Thus, in this study, illite, smectite, and illite-smectite mixed-layer mineral contents are summed and defined as illite-smectite series clay minerals (ISCMs), as in previous works (Jeong et al., 2016). Five dust samples collected in the last 5 years were independently quantified by single-particle analysis using SEM combined with energy dispersive Xray spectroscopy (EDS) analysis, following the method described in the supplement of Jeong et al. (2016).

\subsection{Geochemical analyses}

The major and trace element contents of the soil separates were determined at Activation Laboratories (Ontario, Canada). Dust and soil samples were mixed with a flux of lithium metaborate and lithium tetraborate and then fused in a furnace. The melt was dissolved in a solution of $5 \%$ nitric acid. The solutions were run on a Varian Vista 735 inductively coupled plasma (ICP) emission spectrometer for major elements ( $\mathrm{Si}, \mathrm{Al}, \mathrm{Fe}, \mathrm{Mg}$, Ti, $\mathrm{Mn}, \mathrm{Ca}, \mathrm{Na}, \mathrm{K}$, and $\mathrm{P}$ ) and several trace elements (Ba, Sc, Sr, V, Y, and Zr). The solutions were also run on a Perkin Elmer Sciex ELAN 9000 ICP mass spectrometer for the other trace elements. For the 


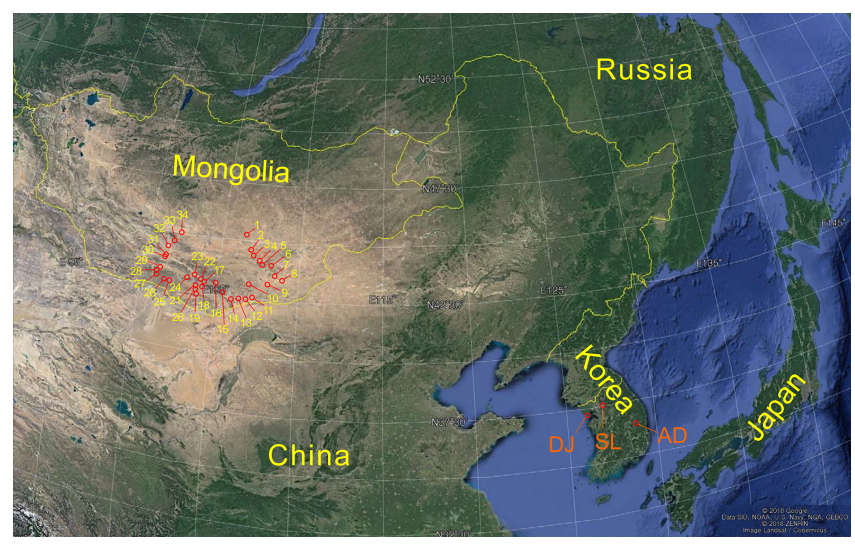

Figure 3. Three sites from which Asian dust samples were obtained on the Korean Peninsula, and the locations from which 34 soil samples were obtained in the Mongolian Gobi Desert. See Table 1 for the sampling site and time during the dust events. AD denotes Andong, DL denotes Deokjeok Island, and SL denotes Seoul.

analysis of selected trace elements $(\mathrm{Cu}, \mathrm{Ni}, \mathrm{Pb}, \mathrm{S}$, and $\mathrm{Zn})$, samples were digested to solutions, using hydrofluoric, nitric, perchloric, and hydrochloric acids, and analyzed using a Varian Vista ICP emission spectrometer. The analytical quality was controlled by using USGS and CANMET certified reference materials for calibrations, internal standards, and duplicate analyses. The detection limits of major elements were under $0.01 \%$, and the detection limits of trace elements are provided in Table 4. Loss on ignition was not measured in either the dust or soil samples. The dust samples prepared for chemical analyses ranged from 30 to $100 \mathrm{mg}$ in weight. $\mathrm{The} \mathrm{Cu}, \mathrm{Ni}, \mathrm{Pb}$, and $\mathrm{Zn}$ contents were only measured for 11 samples that had high enough sample weights.

\section{Results}

\subsection{Mineralogy}

\subsubsection{Asian dust mineralogy}

The mineral compositions of Asian dust determined by XRD are presented in Table 2. Five dusts were independently quantified by SEM-EDS single-particle analyses. The XRD data are in good agreement with the SEM-EDS data, particularly the quartz content, total clay minerals, and ratio of plagioclase to K-feldspar. The SEM-EDS data support the reliability of the XRD quantifications (Table 2). However, the SEMEDS analyses somewhat underestimated the K-feldspar, amphibole, and gypsum contents. This underestimation was due to ambiguity in the interpretation of the EDS patterns of some of the dust particles that are normally present as mixtures of several minerals. For example, K-feldspar is difficult to distinguish from the mixture particle of K-feldspar and IS$\mathrm{CMs}$ because both $\mathrm{K}$ and $\mathrm{Al}$ are major constituents of two phases. Amphibole is difficult to distinguish unambiguously from the mixture particle of ISCMs and calcite. Distinguishing between calcite and gypsum in a mixture is also difficult. Thus, XRD quantification is probably more reliable than SEM-EDS quantification.

Clay minerals accounted for an average of $48 \%$ of the total mineral content. ISCMs were the major clay mineral ( $42 \%$ on average), followed by chlorite (4\%) and kaolinite (2\%) (Table 2). Although ISCMs also contained smectite, they were probably dominated by illite and illite-smectite mixed layers. A weak peak corresponding to expanded smectite was detected by the XRD analysis of ethylene glycol treatment (Jeong, 2008; Park and Jeong, 2016). XRD analysis of clay minerals $(<2 \mu \mathrm{m})$ of Chinese loess, which is a deposit of Asian dust, confirmed that clays are dominated by illite and illite-smectite mixed-layer minerals, with minor amounts of smectite (Jeong et al., 2008).

The quartz content of dust samples was around $20 \%$. Samples of very coarse dust from a 2012 dust event (D10-11; Fig. 2) showed the highest quartz and the lowest clay mineral content (Table 2). The average feldspar (plagioclase and $\mathrm{K}$ feldspar) content was $18 \%$. The average ratio of plagioclase $(12.4 \%)$ to K-feldspar (5.1\%) content was 2.5. Amphibole was detected as a minor mineral ( $2 \%$ on average).

Carbonates and gypsum are important constituents of dust because of their reactivity and solubility. The average content of calcite was $5 \%$, but it varied widely between $0.5 \%$ and $11 \%$. The average content of gypsum was $5 \%$, but this also varied widely (between $0.2 \%$ and $18.3 \%$ ). Dolomite was a minor component that was present in proportions of around $1 \%$. A small quantity of halite was detected only in a dust sample collected on Deokjeok Island (D17) during the 2015 dust event. Although iron oxides (goethite and hematite) are minor minerals $(\sim 1 \%-2 \%)$ responsible for the yellow-brown color of dust, they were not quantified due to their low crystallinity.

\subsubsection{Temporal variation in Asian dust mineralogy}

Figure 4 shows the temporal variation in the mineral content in the dust samples. The clay mineral content varied in the opposite direction to the quartz and feldspar contents. Quartz-rich dust (D11) was sampled during the coarse dust event. The quartz, feldspar, and clay mineral contents do not show any significant correlations with calcite and gypsum contents.

Three sets of intra-event dust samples (sets 1, 5, and 6 in Fig. 4) were collected at the same site. Set 1 samples showed little intra-event variation, while set 6 samples showed clear increases in clay and gypsum contents toward the end of the dust event, along with decreases in quartz, feldspar, and calcite contents. Set 5 samples showed a decrease in the claymineral content but with no notable change in quartz content.

The other sets of dust samples (sets 2-4 in Fig. 4) were collected at different sites during the same dust event and 
Table 2. Mineral compositions of Asian dust (wt \%) determined by X-ray diffraction.

\begin{tabular}{|c|c|c|c|c|c|c|c|c|c|c|c|c|c|c|}
\hline Sample & $\mathrm{Qtz}^{1}$ & $\mathrm{Pl}$ & Kfs & Ilt & $\begin{array}{r}\mathrm{Mix} \\
+\mathrm{Sm}\end{array}$ & ISCMs $^{2}$ & Chl & $\mathrm{K} \ln$ & Amp & $\mathrm{Cal}$ & Dol & $\mathrm{Gp}$ & $\mathrm{Hl}$ & $\begin{array}{l}\text { Total } \\
\text { clays }^{3}\end{array}$ \\
\hline D1 & 23.6 & 14.6 & 5.4 & 23.4 & 15.0 & 38.4 & 4.6 & 2.6 & 2.2 & 4.4 & 1.2 & 2.7 & 0.0 & 45.7 \\
\hline D2 & 24.2 & 13.9 & 6.8 & 22.1 & 19.5 & 41.6 & 3.1 & 1.4 & 2.7 & 3.1 & 2.0 & 1.3 & 0.0 & 46.2 \\
\hline D3 & 23.5 & 14.3 & 3.8 & 15.4 & 19.7 & 35.1 & 3.4 & 2.1 & 1.0 & 5.4 & 1.9 & 9.5 & 0.0 & 40.6 \\
\hline D4 & 18.0 & 12.2 & 4.7 & 23.1 & 12.0 & 35.1 & 5.9 & 3.1 & 2.4 & 4.4 & 2.4 & 11.7 & 0.0 & 44.0 \\
\hline D5 & 21.1 & 12.7 & 4.8 & 23.1 & 10.7 & 33.8 & 5.4 & 2.8 & 1.7 & 6.8 & 2.6 & 8.3 & 0.0 & 42.0 \\
\hline D6 & 18.2 & 10.9 & 4.8 & 25.4 & 8.7 & 34.1 & 5.7 & 3.1 & 2.1 & 8.7 & 2.6 & 9.7 & 0.0 & 42.9 \\
\hline D7 & 21.5 & 13.0 & 3.4 & 16.4 & 26.0 & 42.4 & 4.4 & 3.1 & 0.8 & 6.3 & 1.0 & 4.2 & 0.0 & 49.9 \\
\hline D8 & 18.7 & 12.6 & 6.0 & 23.0 & 22.9 & 45.9 & 4.5 & 2.1 & 2.7 & 3.8 & 1.1 & 2.5 & 0.0 & 52.5 \\
\hline D9 & 21.9 & 14.0 & 5.7 & 21.5 & 22.4 & 43.9 & 4.1 & 1.1 & 1.9 & 4.6 & 2.5 & 0.2 & 0.0 & 49.1 \\
\hline D10 & 28.7 & 17.5 & 5.6 & 11.6 & 21.9 & 33.5 & 3.5 & 2.3 & 0.9 & 6.3 & 0.8 & 0.8 & 0.0 & 39.3 \\
\hline D11 & 31.0 & 17.5 & 6.8 & 18.3 & 10.2 & 28.5 & 3.8 & 1.5 & 2.5 & 6.2 & 1.4 & 0.5 & 0.0 & 33.8 \\
\hline D12 & 19.1 & 12.2 & 7.1 & 19.5 & 14.2 & 33.7 & 2.2 & 1.8 & 2.1 & 1.2 & 2.4 & 18.3 & 0.0 & 37.8 \\
\hline D13 & 17.9 & 12.3 & 6.1 & 23.6 & 23.9 & 47.5 & 3.8 & 1.3 & 1.9 & 5.5 & 0.6 & 3.0 & 0.0 & 52.6 \\
\hline D14 & 18.3 & 13.4 & 5.3 & 12.5 & 35.4 & 47.9 & 1.8 & 1.9 & 1.0 & 0.5 & 0.4 & 9.4 & 0.0 & 51.6 \\
\hline D15 & 20.1 & 10.9 & 3.1 & 15.5 & 37.7 & 53.2 & 3.7 & 2.2 & 1.0 & 4.1 & 0.7 & 1.0 & 0.0 & 59.1 \\
\hline D16 & 19.7 & 11.3 & 3.7 & 16.1 & 33.4 & 49.5 & 3.7 & 2.7 & 1.0 & 3.4 & 0.6 & 4.3 & 0.0 & 56.0 \\
\hline D17 & 19.7 & 10.4 & 4.2 & 15.4 & 36.1 & 51.5 & 3.7 & 2.6 & 0.7 & 3.8 & 0.3 & 2.1 & 0.9 & 57.9 \\
\hline D18 & 19.0 & 10.5 & 4.3 & 13.7 & 38.2 & 51.9 & 3.1 & 1.7 & 1.3 & 2.8 & 0.5 & 5.1 & 0.0 & 56.7 \\
\hline D19 & 17.4 & 9.9 & 4.5 & 14.0 & 33.4 & 47.4 & 2.8 & 2.7 & 1.2 & 6.2 & 1.5 & 6.4 & 0.0 & 53.0 \\
\hline D20 & 17.1 & 10.5 & 5.7 & 23.5 & 15.7 & 39.2 & 4.1 & 2.0 & 2.4 & 9.2 & 1.9 & 8.0 & 0.0 & 45.3 \\
\hline D21 & 24.7 & 14.9 & 5.0 & 21.2 & 12.7 & 33.9 & 3.9 & 2.0 & 3.0 & 11.0 & 1.4 & 0.0 & 0.0 & 39.9 \\
\hline D22 & 19.9 & 10.5 & 4.0 & 22.5 & 18.8 & 41.3 & 4.4 & 2.0 & 3.8 & 8.5 & 2.4 & 3.3 & 0.0 & 47.7 \\
\hline D23 & 14.1 & 9.0 & 4.9 & 26.8 & 19.6 & 46.4 & 5.0 & 2.4 & 2.6 & 5.2 & 2.6 & 7.9 & 0.0 & 53.8 \\
\hline D24 & 19.0 & 10.6 & 6.1 & 14.0 & 32.4 & 46.4 & 4.8 & 1.3 & 3.0 & 3.8 & 1.3 & 3.6 & 0.0 & 52.5 \\
\hline D25 & 19.6 & 11.4 & 6.0 & 23.7 & 25.8 & 49.5 & 4.4 & 1.2 & 2.2 & 2.9 & 0.8 & 2.1 & 0.0 & 55.1 \\
\hline Average & 20.6 & 12.4 & 5.1 & 19.4 & 22.6 & 42.1 & 4.0 & 2.1 & 1.9 & 5.1 & 1.5 & 5.0 & 0.0 & 48.2 \\
\hline $\mathrm{SD}$ & 3.7 & 2.2 & 1.1 & 4.5 & 9.3 & 7.1 & 1.0 & 0.6 & 0.8 & 2.5 & 0.8 & 4.4 & & 6.9 \\
\hline \multicolumn{15}{|c|}{ Mineral compositions determined by SEM single-particle analysis } \\
\hline D13 & 19.0 & 10.9 & 3.8 & & & 53.8 & 2.4 & 1.1 & 0.7 & 7.0 & 0.8 & 0.5 & 0.0 & 57.3 \\
\hline D18 & 19.5 & 9.3 & 3.4 & & & 55.7 & 2.6 & 2.3 & 0.3 & 4.4 & 0.2 & 2.1 & 0.0 & 60.7 \\
\hline D19 & 16.9 & 7.9 & 2.6 & & & 50.2 & 4.9 & 2.3 & 0.6 & 9.4 & 2.5 & 2.7 & 0.0 & 57.4 \\
\hline D22 & 19.0 & 11.7 & 3.7 & & & 43.2 & 6.3 & 3.5 & 0.2 & 8.8 & 0.7 & 2.8 & 0.0 & 53.0 \\
\hline D24 & 21.0 & 9.7 & 4.4 & & & 50.9 & 4.0 & 1.5 & 0.8 & 4.8 & 0.8 & 2.0 & 0.0 & 56.4 \\
\hline $\mathrm{SEM}^{4}$ & 19.1 & 9.9 & 3.6 & & & 50.8 & 4.1 & 2.1 & 0.5 & 6.9 & 1.0 & 2.0 & 0.0 & 56.9 \\
\hline $\mathrm{XRD}^{4}$ & 18.6 & 10.8 & 5.0 & & & 46.9 & 3.8 & 1.8 & 2.2 & 5.4 & 1.3 & 4.3 & 0.0 & 52.5 \\
\hline
\end{tabular}

${ }^{1}$ The following abbreviations are used in the table: Qtz, quartz; Pl, plagioclase; Kf, K-feldspar; Ilt, illite; Mix, illite-smectite mixed layers; Sm, smectite; ISCMs, illite-smectite series clay minerals; Chl, chlorite; Kln, kaolinite; Amp, amphibole; Cal, calcite; Dol, dolomite; Gp, gypsum; Hl, halite. ${ }^{2}$ ISCMs include illite, smectite, and illite-smectite mixed layers. ${ }^{3}$ Total clays are the sum of ISCMs, chlorite, and kaolinite. ${ }^{4}$ Average of five samples.

showed little spatial variation in mineral composition. However, in set 3, the gypsum content in samples from Deokjeok Island (D14) was far higher than in samples from Andong (D13).

\subsubsection{Soil mineralogy}

The mineral compositions of surface soils $(<20 \mu \mathrm{m})$ in the Mongolian Gobi Desert are presented in Table S1 in the Supplement. The mineral compositions varied among samples, probably according to the local geology. The total clay mineral content ranged widely among samples, from
$25.3 \%(\mathrm{G} 18)$ to $67.4 \%(\mathrm{G} 34)$. This range was wider than that among the dust samples $(33.8 \%-59.1 \%)$. Clay minerals were dominated by ISCMs, followed by chlorite $(4.3 \%)$ and kaolinite $(3.0 \%)$. XRD analyses of clays $(<2 \mu \mathrm{m})$ treated with ethylene glycol revealed variation in the smectite content (Fig. S2). Although some samples were enriched with smectite (sample G34), the XRD intensities of smectite were generally weak; illite and illite-smectite mixed layers tended to dominate ISCMs. The quartz content varied widely among samples, from $8.8 \%$ (G34) to $32.1 \%$ (G18). The average ratio of plagioclase $(14.3 \%)$ to K-feldspar $(5.5 \%)$ was ap- 


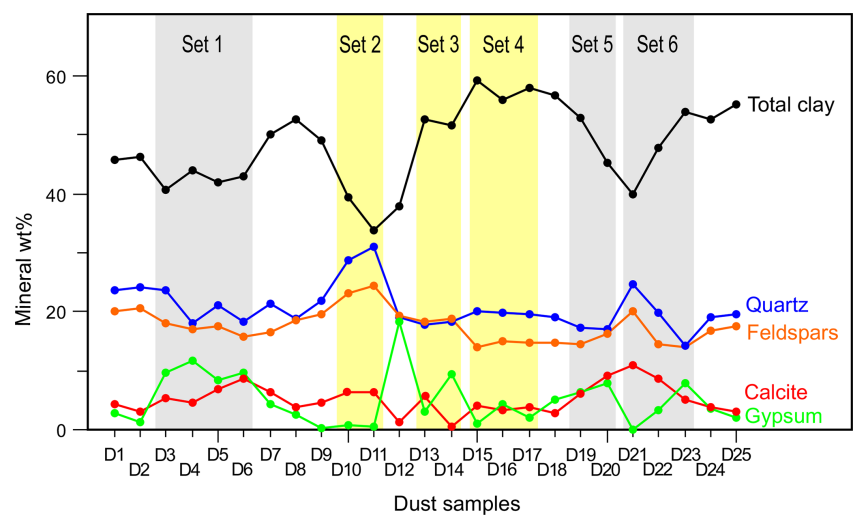

Figure 4. Time-series variation in the major mineral contents of Asian dust. Sample collection dates are provided in Table 1. Dust sample sets 1,5 , and 6 comprise serial samples collected during individual dust events. Dust sample sets $2-4$ comprise samples collected at different sites during individual dust events.

proximately 2.6. Calcite contents were $9.5 \%$ on average. Soil samples G2, G19, and G28 exhibited calcite enrichment (> $20 \%$ ). The calcite-rich samples were abundant in limestone pebbles (G2) and in secondary calcite precipitates (G19 and G28). Gypsum was a minor component of source soils ( $0.6 \%$ on average), but it was more abundant in samples G22 $(5.6 \%)$ and G31 (3.2\%) from dry lake beds and in sample G25 (4.4\%) from a dry river bed.

\subsubsection{Comparison of mineralogy between Asian dust and soil samples}

Mineral compositions are compared between the source soils and Asian dust samples in the box and whiskers plot shown in Fig. 5. The plot shows similar ranges of mineral contents between the Asian dust and source soil samples. Calcite and gypsum contents, however, differed between dust and soil samples. In source soils, gypsum was only present in trace amounts (average content of $0.6 \%$ ), whereas calcite was abundant (average content of 9.5\%) (Table S1, Fig. 5). In the dust samples, however, the average gypsum content was $5 \%$, whereas the average calcite content was $5.1 \%$ (Table 2, Fig. 5).

\subsection{Geochemistry}

\subsubsection{Comparison of geochemistry between Asian dust and soil samples}

The major element compositions of dust samples were recalculated on a volatile-free basis and are presented as metal percentage by weight (wt \%) values (Table 3). Trace element compositions of dust samples are listed in Table 4. The major and trace element compositions of the source soil samples are listed in Tables S2 and S3, respectively. The contents of major and trace elements of Asian dust and source

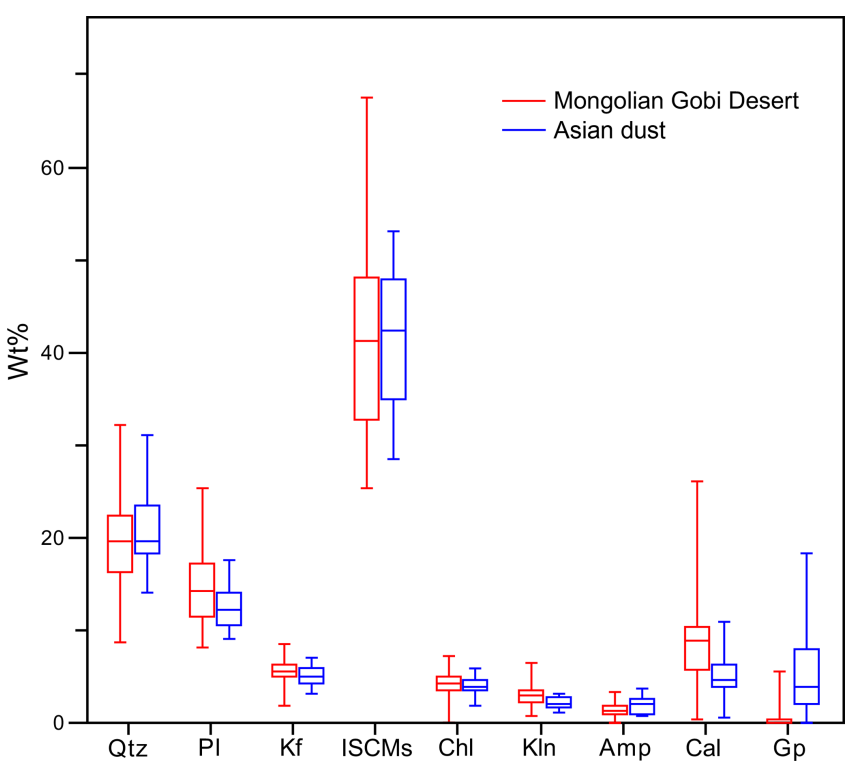

Figure 5. Box and whiskers plot showing the mineral compositions of Asian dust and source soil samples. The top and bottom of the box define the third and first quartiles, respectively. The horizontal line in the center of the box is the second quartile, which is the median. The two ends of the vertical line crossing each box indicate the minimum and maximum. The following abbreviations are used in the figure: Amp, amphibole; Cal, calcite; Chl, chlorite; Gp, gypsum; ISCMs, illite-smectite series clay minerals; Kln, kaolinite; Kf, K-feldspar; Pl, plagioclase; and Qtz, quartz.

soil samples were normalized by the average values for the upper continental crust (UCC; Rudnick and Gao, 2003) and are presented in Figs. 6-8.

Major element compositions of both the dust and soil samples did not coincide with the average UCC values (enrichment factor of 1). Si and $\mathrm{Na}$ were relatively depleted in dust and soils, compared with the average UCC (enrichment factor $<1$ ), whereas $\mathrm{Al}, \mathrm{Fe}, \mathrm{Mn}, \mathrm{Mg}, \mathrm{Ca}, \mathrm{K}, \mathrm{Ti}$, and $\mathrm{P}$ were relatively enriched in dust and soils (enrichment factor $>1$ ) (Fig. 6). In general, the range of the major element contents of Asian dust samples coincided with those of source soils (Fig. 6). However, $\mathrm{Al}, \mathrm{Fe}, \mathrm{Mn}, \mathrm{Mg}, \mathrm{K}$, and $\mathrm{P}$ were slightly enriched in dust compared with soils. The ranges of the $\mathrm{Al}$, $\mathrm{Fe}, \mathrm{K}$, and $\mathrm{Ti}$ contents of dust samples were narrower than those of source soils. The ranges of the $\mathrm{Ca}$ and $\mathrm{Na}$ contents were wide in both the dust and soil samples.

The UCC-normalized trace element composition data showed that dust samples were significantly enriched with $\mathrm{Cu}, \mathrm{Zn}, \mathrm{Sn}, \mathrm{Pb}$, and $\mathrm{S}$ relative to the source soil samples (Fig. 7). The dust samples were slightly enriched with $\mathrm{Cr}$, Co, $\mathrm{Ni}, \mathrm{Sb}$, and $\mathrm{Ba}$ relative to the soil samples, whereas $\mathrm{Sr}, \mathrm{Y}, \mathrm{Zr}$, Hf, and Ta were slightly depleted in dust (Fig. 7). Compared with the soil samples, the rare earth elements (REEs) of dust indicated the systematic depletion of heavy REEs (Tb-Lu) relative to light REEs (La-Nd) (Fig. 8). The contents of V, 
Table 3. Major element composition of Asian dust (in wt \%) on a volatile-free basis.

\begin{tabular}{|c|c|c|c|c|c|c|c|c|c|c|c|c|}
\hline Sample & $\mathrm{Si}$ & $\mathrm{Al}$ & $\mathrm{Fe}$ & Mn & $\mathrm{Mg}$ & $\mathrm{Ca}$ & $\mathrm{Na}$ & $\mathrm{K}$ & $\mathrm{Ti}$ & $\mathrm{P}$ & Total & CIA* \\
\hline D1 & 28.08 & 9.32 & 5.27 & 0.11 & 2.00 & 3.97 & 1.05 & 2.68 & 0.52 & 0.12 & 53.11 & 70.3 \\
\hline D2 & 28.48 & 9.17 & 5.19 & 0.12 & 1.83 & 3.54 & 1.20 & 2.75 & 0.53 & 0.16 & 52.97 & 68.1 \\
\hline D3 & 26.65 & 8.61 & 4.83 & 0.09 & 2.40 & 6.62 & 1.78 & 2.49 & 0.48 & 0.11 & 54.06 & 62.0 \\
\hline D4 & 25.67 & 9.17 & 5.28 & 0.11 & 2.65 & 6.59 & 1.57 & 2.71 & 0.48 & 0.12 & 54.34 & 64.7 \\
\hline D5 & 25.66 & 9.62 & 5.16 & 0.10 & 2.46 & 6.68 & 1.39 & 2.54 & 0.49 & 0.10 & 54.22 & 68.0 \\
\hline D6 & 24.98 & 9.08 & 5.17 & 0.11 & 2.68 & 7.93 & 1.47 & 2.77 & 0.47 & 0.12 & 54.75 & 65.2 \\
\hline D7 & 26.93 & 9.24 & 5.15 & 0.11 & 2.39 & 5.30 & 1.26 & 2.69 & 0.51 & 0.11 & 53.69 & 67.9 \\
\hline D8 & 27.24 & 9.69 & 5.54 & 0.11 & 2.20 & 3.87 & 1.17 & 2.80 & 0.54 & 0.19 & 53.35 & 69.5 \\
\hline D9 & 28.11 & 9.02 & 5.35 & 0.11 & 2.05 & 3.82 & 1.05 & 2.83 & 0.51 & 0.26 & 53.12 & 69.0 \\
\hline D10 & 27.72 & 8.38 & 4.95 & 0.11 & 2.15 & 5.34 & 1.91 & 2.42 & 0.51 & 0.12 & 53.61 & 60.5 \\
\hline D11 & 28.82 & 8.47 & 4.69 & 0.10 & 1.76 & 4.61 & 1.50 & 2.47 & 0.51 & 0.12 & 53.06 & 64.3 \\
\hline D12 & 25.19 & 9.00 & 5.56 & 0.15 & 1.99 & 7.27 & 1.89 & 3.03 & 0.53 & 0.19 & 54.78 & 60.6 \\
\hline D13 & 26.64 & 9.51 & 5.23 & 0.14 & 2.31 & 4.46 & 1.93 & 2.91 & 0.53 & 0.16 & 53.80 & 61.9 \\
\hline D14 & 27.59 & 9.37 & 5.35 & 0.13 & 1.89 & 3.80 & 1.42 & 3.16 & 0.55 & 0.16 & 53.42 & 65.1 \\
\hline D15 & 27.85 & 9.73 & 5.26 & 0.13 & 2.08 & 3.58 & 1.01 & 2.80 & 0.54 & 0.12 & 53.09 & 71.2 \\
\hline D16 & 27.59 & 9.60 & 5.38 & 0.13 & 2.10 & 3.91 & 1.09 & 2.80 & 0.53 & 0.13 & 53.26 & 70.0 \\
\hline D17 & 27.62 & 9.58 & 5.29 & 0.13 & 2.10 & 3.63 & 1.53 & 2.78 & 0.50 & 0.12 & 53.28 & 65.8 \\
\hline D18 & 28.09 & 9.44 & 5.17 & 0.12 & 2.03 & 3.61 & 1.21 & 2.79 & 0.52 & 0.11 & 53.09 & 68.5 \\
\hline D19 & 25.73 & 9.25 & 5.35 & 0.12 & 2.67 & 5.93 & 1.69 & 2.90 & 0.51 & 0.14 & 54.29 & 63.3 \\
\hline D20 & 25.22 & 8.89 & 5.29 & 0.12 & 2.53 & 7.45 & 1.71 & 2.86 & 0.51 & 0.15 & 54.71 & 62.3 \\
\hline D21 & 27.77 & 8.55 & 4.93 & 0.12 & 1.98 & 5.80 & 1.15 & 2.62 & 0.49 & 0.14 & 53.54 & 67.6 \\
\hline D22 & 25.96 & 9.36 & 5.76 & 0.12 & 2.47 & 5.98 & 1.11 & 2.66 & 0.50 & 0.17 & 54.09 & 69.7 \\
\hline D23 & 25.11 & 9.64 & 5.77 & 0.12 & 3.12 & 6.02 & 1.07 & 2.91 & 0.50 & 0.14 & 54.38 & 70.0 \\
\hline D24 & 27.75 & 9.62 & 5.31 & 0.11 & 2.11 & 3.68 & 1.09 & 2.90 & 0.50 & 0.12 & 53.19 & 69.8 \\
\hline D25 & 28.36 & 9.78 & 5.43 & 0.12 & 1.90 & 2.80 & 0.84 & 2.82 & 0.55 & 0.19 & 52.78 & 73.0 \\
\hline Average & 26.99 & 9.24 & 5.27 & 0.12 & 2.23 & 5.05 & 1.36 & 2.76 & 0.51 & 0.14 & 53.68 & 66.7 \\
\hline $\mathrm{SD}$ & 1.21 & 0.41 & 0.25 & 0.01 & 0.33 & 1.48 & 0.32 & 0.17 & 0.02 & 0.04 & 0.62 & 3.5 \\
\hline
\end{tabular}

* CIA stands for the chemical index of alteration (Nesbitt and Young, 1982).

$\mathrm{Ga}$, Th, and $\mathrm{U}$ showed little difference between the dust and soil samples.

\subsubsection{Temporal variation of Asian dust geochemistry}

Time-series data of UCC-normalized major element contents are provided in Fig. 9. The $\mathrm{Si}, \mathrm{Al}, \mathrm{Fe}$, and Ti contents showed little fluctuation within an enrichment factor of \pm 0.5 . However, $\mathrm{Ca}, \mathrm{Mg}$, and $\mathrm{Na}$ contents exhibited large fluctuations over time.

Time-series data of UCC-normalized trace element contents showed that REEs and $\mathrm{Zr}$ exhibited small variations around an enrichment factor of 1 , whereas $\mathrm{Sn}$ fluctuated significantly (Fig. 10). Analyses of $\mathrm{Cu}, \mathrm{Zn}$, and $\mathrm{Pb}$ were only carried out for 11 samples (Table 4), due to limited sample quantity, and are not shown in Fig. 10. Their enrichment factors varied greatly (between 1 and 100).

\section{Discussion}

\subsection{Source of Asian dust}

Previous backward trajectory analysis (Jeong, 2008) and satellite remote sensing data (Husar et al., 2001; Zhang et al., 2003; Xuan et al., 2004; Seinfeld et al., 2004; McKendry et al., 2008; Jeong et al., 2014) have indicated that the Mongolian and northern Chinese deserts are the source of Asian dust transported to Korea. The satellite images of dust in this study confirmed that most dust outbreaks occurred in the Gobi Desert and sandy deserts distributed from southern Mongolia to northern China (Fig. 1a). The Taklamakan Desert is another source of Asian dust west of the Gobi Desert (Zhang, et al., 2003; Xuan et al., 2004). Unfortunately, the Taklamakan Desert was not included in the available satellite images. Although Figs. 1a and S1 are based on only one satellite image for the outbreak of each dust event, serial images acquired at an interval of $1 \mathrm{~h}$ or below around dust outbreaks revealed no notable migration of dust storms from west of the Gobi Desert. Mineral compositions of Asian dust coincided with fine $(<20 \mu \mathrm{m})$ surface soils sampled in the Mongolian Gobi Desert (Fig. 5). Lower calcite and higher 
Table 4. Trace element composition of Asian dust (in ppm).

\begin{tabular}{|c|c|c|c|c|c|c|c|c|c|c|c|c|c|}
\hline Sample & $\mathrm{S}$ & $\mathrm{Sc}$ & V & $\mathrm{Cr}$ & $\mathrm{Co}$ & $\mathrm{Ni}$ & $\mathrm{Cu}$ & $\mathrm{Zn}$ & $\mathrm{Ga}$ & $\mathrm{Rb}$ & $\mathrm{Sr}$ & $\mathrm{Y}$ & $\mathrm{Zr}$ \\
\hline $\mathrm{LOD}^{1}$ & 10 & 1 & 5 & 20 & 1 & 1 & 1 & 1 & 1 & 1 & 2 & 0.5 & 1 \\
\hline D1 & - & 14 & 113 & 110 & 22 & - & - & - & 20 & 111 & 225 & 27.6 & 128 \\
\hline D2 & - & 13 & 113 & 110 & 33 & - & - & - & 18 & 107 & 217 & 26.9 & 139 \\
\hline D3 & - & 12 & 97 & 100 & 16 & - & - & - & 17 & 91 & 297 & 23.6 & 128 \\
\hline D4 & 2190 & 14 & 116 & 100 & 19 & 55 & 1280 & 500 & 19 & 101 & 326 & 24.9 & 119 \\
\hline D5 & - & 12 & 100 & 100 & 20 & - & - & - & 17 & 82 & 268 & 21.3 & 106 \\
\hline D6 & - & 13 & 111 & 190 & 17 & - & - & - & 18 & 99 & 315 & 23.2 & 108 \\
\hline D7 & 899 & 15 & 114 & 80 & 19 & 53 & 155 & 239 & 20 & 103 & 275 & 28.4 & 137 \\
\hline D8 & - & 13 & 101 & 100 & 19 & - & - & - & 19 & 101 & 208 & 25.7 & 111 \\
\hline D9 & - & 14 & 107 & 100 & 18 & - & - & - & 18 & 112 & 210 & 26.4 & 129 \\
\hline D10 & 1150 & 12 & 99 & 100 & 19 & 65 & 448 & 823 & 15 & 86 & 251 & 24.4 & 136 \\
\hline D11 & 440 & 12 & 96 & 100 & 17 & 54 & 218 & 415 & 18 & 103 & 237 & 26.7 & 148 \\
\hline D12 & - & 10 & 141 & 160 & 17 & - & - & - & 20 & 91 & 242 & 19.8 & 144 \\
\hline D13 & - & 12 & 102 & 90 & 18 & - & - & - & 18 & 91 & 224 & 22.4 & 106 \\
\hline D14 & 2500 & 12 & 113 & 100 & 18 & 68 & 1330 & 900 & 23 & 109 & 218 & 26.5 & 141 \\
\hline D15 & 420 & 15 & 118 & 190 & 20 & 53 & 166 & 157 & 21 & 115 & 218 & 29.7 & 125 \\
\hline D16 & 983 & 15 & 119 & 120 & 20 & 56 & 401 & 236 & 20 & 110 & 219 & 28.0 & 121 \\
\hline D17 & 581 & 14 & 104 & 80 & 19 & 51 & 219 & 184 & 20 & 108 & 203 & 26.6 & 108 \\
\hline D18 & 1190 & 13 & 108 & 90 & 19 & 53 & 2840 & 349 & 20 & 108 & 217 & 27.7 & 121 \\
\hline D19 & - & 13 & 97 & 110 & 18 & 34 & 1436 & 733 & 19 & 99 & 298 & 24.9 & 141 \\
\hline D20 & - & 12 & 95 & 100 & 16 & - & - & - & 17 & 88 & 290 & 21.8 & 144 \\
\hline $\mathrm{D} 21$ & - & 13 & 99 & 140 & 19 & - & - & - & 17 & 96 & 249 & 25.2 & 121 \\
\hline $\mathrm{D} 22$ & - & 14 & 123 & 110 & 21 & - & - & - & 19 & 100 & 272 & 26.6 & 116 \\
\hline $\mathrm{D} 23$ & - & 14 & 116 & 110 & 19 & - & - & - & 20 & 102 & 309 & 23.8 & 109 \\
\hline $\mathrm{D} 24$ & - & 14 & 105 & 100 & 19 & - & - & - & 19 & 109 & 210 & 25.7 & 109 \\
\hline D25 & 673 & 15 & 117 & 80 & 20 & 50 & 692 & 378 & 20 & 115 & 188 & 28.8 & 134 \\
\hline Average & 1103 & 13 & 109 & 111 & 19 & 54 & 835 & 447 & 19 & 101 & 247 & 25.5 & 125 \\
\hline Sample & $\mathrm{Nb}$ & Sn & $\mathrm{Sb}$ & $\mathrm{Cs}$ & $\mathrm{Ba}$ & $\mathrm{Hf}$ & $\mathrm{Ta}$ & $\mathrm{Tl}$ & $\mathrm{Pb}$ & Th & $\mathrm{U}$ & $\mathrm{La}$ & $\mathrm{Ce}$ \\
\hline $\mathrm{LOD}^{1}$ & 0.2 & 1 & 0.2 & 0.1 & 2 & 0.1 & 0.01 & 0.05 & 3 & 0.05 & 0.01 & 0.05 & 0.05 \\
\hline D1 & 14.3 & 12 & 1.3 & 8.6 & 620 & 4.0 & 0.82 & 0.89 & - & 12.7 & 2.72 & 46.7 & 90.7 \\
\hline D2 & 12.4 & 61 & 0.3 & 8.6 & 622 & 3.7 & 0.72 & 0.72 & - & 12.2 & 2.73 & 41.3 & 81.0 \\
\hline D3 & 10.6 & 26 & 0.9 & 7.9 & 549 & 3.9 & 0.73 & 0.62 & - & 11.2 & 3.59 & 36.0 & 70.6 \\
\hline D4 & 11.6 & 29 & 4.5 & 9.1 & 571 & 3.4 & 0.69 & 0.86 & 250 & 11.9 & 3.78 & 35.5 & 71.7 \\
\hline D5 & 10.3 & 40 & 1.3 & 7.4 & 546 & 3.1 & 0.34 & 0.68 & - & 9.8 & 3.04 & 30.7 & 61.6 \\
\hline D6 & 11.0 & 39 & 2.6 & 8.4 & 589 & 3.0 & 0.69 & 0.60 & - & 11.3 & 3.64 & 33.1 & 66.5 \\
\hline D7 & 11.8 & 4 & 0.7 & 8.6 & 562 & 3.6 & 0.73 & 0.50 & 66 & 12.1 & 3.24 & 41.1 & 82.4 \\
\hline D8 & 12.1 & 7 & $<0.2$ & 8.3 & 519 & 3.8 & 0.65 & 0.56 & - & 11.2 & 2.84 & 37.3 & 75.7 \\
\hline D9 & 11.6 & 6 & $<0.2$ & 9.0 & 568 & 4.2 & 0.69 & 0.68 & - & 11.8 & 2.69 & 36.6 & 73.2 \\
\hline D10 & 13.0 & 5 & 0.2 & 6.5 & 589 & 3.9 & 0.59 & 0.44 & 199 & 10.9 & 2.50 & 44.1 & 85.5 \\
\hline D11 & 11.6 & 4 & 0.8 & 7.0 & 650 & 4.4 & 0.86 & 0.48 & 80 & 11.9 & 2.79 & 45.3 & 87.9 \\
\hline D12 & 10.8 & 96 & 4.0 & 7.7 & 788 & 4.0 & 0.67 & 1.17 & - & 10.1 & 2.85 & 34.4 & 63.5 \\
\hline D13 & 10.3 & 10 & 0.9 & 7.6 & 507 & 2.9 & 0.55 & 0.61 & - & 10.0 & 2.73 & 33.0 & 65.4 \\
\hline D14 & 11.5 & 41 & 2.9 & 8.9 & 699 & 4.2 & 0.77 & 0.87 & 264 & 12.6 & 3.07 & 38.6 & 77.1 \\
\hline D15 & 11.9 & 3 & 0.5 & 9.3 & 606 & 3.7 & 0.89 & 0.50 & 41 & 12.9 & 2.72 & 41.7 & 84.9 \\
\hline D16 & 12.5 & 3 & $<0.2$ & 9.0 & 612 & 3.6 & 0.77 & 0.47 & 78 & 12.2 & 2.71 & 40.5 & 82.7 \\
\hline D17 & 11.3 & 2 & $<0.2$ & 8.7 & 569 & 3.3 & 0.66 & 0.27 & 61 & 11.5 & 2.35 & 37.5 & 74.4 \\
\hline D18 & 12.7 & 3 & $<0.2$ & 8.8 & 599 & 3.5 & 0.79 & 0.53 & 104 & 11.7 & 2.59 & 38.0 & 77.8 \\
\hline D19 & 12.2 & 56 & 5.0 & 8.0 & 747 & 3.9 & 0.77 & 0.48 & 72.5 & 11.7 & 3.43 & 35.9 & 72.3 \\
\hline D20 & 10.4 & 39 & 1.9 & 6.7 & 778 & 4.1 & 0.58 & 0.52 & - & 10.9 & 3.28 & 32.6 & 64.4 \\
\hline $\mathrm{D} 21$ & 13.0 & 6 & 1.0 & 6.8 & 627 & 3.1 & 0.75 & 0.31 & - & 11.0 & 2.85 & 44.7 & 89.2 \\
\hline $\mathrm{D} 22$ & 12.1 & 7 & 2.4 & 8.2 & 625 & 3.5 & 0.84 & 0.55 & - & 12.2 & 3.30 & 43.8 & 84.4 \\
\hline D23 & 10.6 & 14 & 8.5 & 9.3 & 583 & 3.3 & 0.66 & 0.97 & - & 12.3 & 3.96 & 37.1 & 71.5 \\
\hline D24 & 12.4 & 3 & 1.1 & 8.9 & 597 & 3.2 & 0.79 & 0.53 & - & 11.5 & 2.39 & 38.6 & 77.5 \\
\hline D25 & 13.9 & 5 & 1.5 & 9.5 & 602 & 4.0 & 0.93 & 0.50 & 195 & 13.5 & 2.72 & 42.7 & 88.2 \\
\hline Average & 11.8 & 21 & 1.7 & 8.3 & 613 & 3.7 & 0.72 & 0.61 & 116 & 11.6 & 3.0 & 38.7 & 76.8 \\
\hline
\end{tabular}


Table 4. Continued.

\begin{tabular}{|c|c|c|c|c|c|c|c|c|c|c|c|c|c|c|}
\hline $\begin{array}{l}\text { Sample } \\
\text { LOD }^{1}\end{array}$ & $\begin{array}{r}\operatorname{Pr} \\
0.01\end{array}$ & $\begin{array}{r}\mathrm{Nd} \\
0.05\end{array}$ & $\begin{array}{r}\mathrm{Sm} \\
0.01\end{array}$ & $\begin{array}{r}\mathrm{Eu} \\
0.005\end{array}$ & $\begin{array}{r}\mathrm{Gd} \\
0.01\end{array}$ & $\begin{array}{r}\mathrm{Tb} \\
0.01\end{array}$ & $\begin{array}{r}\text { Dy } \\
0.01\end{array}$ & $\begin{array}{r}\text { Ho } \\
0.01\end{array}$ & $\begin{array}{r}\mathrm{Er} \\
0.01\end{array}$ & $\begin{array}{r}\text { Tm } \\
0.005\end{array}$ & $\begin{array}{r}\mathrm{Yb} \\
0.01\end{array}$ & $\begin{array}{r}\mathrm{Lu} \\
0.002\end{array}$ & $(\mathrm{La} / \mathrm{Yb})_{\mathrm{N}}{ }^{2}$ & $\mathrm{Eu} / \mathrm{Eu}^{* 2}$ \\
\hline D1 & 9.83 & 36.5 & 6.55 & 1.50 & 5.24 & 0.77 & 4.73 & 0.93 & 2.61 & 0.388 & 2.51 & 0.374 & 12.5 & 0.78 \\
\hline D2 & 8.42 & 31.0 & 6.44 & 1.33 & 5.51 & 0.81 & 4.63 & 0.87 & 2.47 & 0.348 & 2.23 & 0.348 & 12.5 & 0.68 \\
\hline D3 & 7.39 & 27.5 & 5.55 & 1.07 & 4.52 & 0.69 & 4.34 & 0.84 & 2.27 & 0.332 & 2.26 & 0.330 & 10.7 & 0.65 \\
\hline D4 & 7.62 & 26.7 & 5.64 & 1.04 & 4.30 & 0.67 & 3.98 & 0.76 & 2.33 & 0.331 & 2.30 & 0.329 & 10.4 & 0.65 \\
\hline D5 & 6.51 & 25.2 & 4.78 & 1.02 & 4.01 & 0.65 & 3.79 & 0.72 & 1.99 & 0.287 & 1.84 & 0.261 & 11.2 & 0.71 \\
\hline D6 & 6.87 & 24.6 & 4.79 & 1.00 & 4.29 & 0.66 & 3.82 & 0.76 & 2.32 & 0.336 & 2.30 & 0.356 & 9.7 & 0.67 \\
\hline D7 & 9.19 & 32.9 & 6.09 & 1.34 & 5.11 & 0.75 & 4.64 & 0.91 & 2.65 & 0.411 & 2.64 & 0.390 & 10.5 & 0.73 \\
\hline D8 & 8.00 & 29.4 & 5.55 & 1.33 & 4.85 & 0.76 & 4.40 & 0.91 & 2.46 & 0.359 & 2.44 & 0.349 & 10.3 & 0.78 \\
\hline D9 & 8.13 & 30.8 & 6.27 & 1.30 & 4.92 & 0.78 & 4.51 & 0.85 & 2.50 & 0.391 & 2.29 & 0.343 & 10.8 & 0.72 \\
\hline D10 & 9.33 & 35.5 & 6.47 & 1.24 & 4.48 & 0.71 & 4.29 & 0.81 & 2.45 & 0.323 & 2.10 & 0.314 & 14.2 & 0.70 \\
\hline D11 & 9.74 & 36.7 & 6.50 & 1.30 & 5.14 & 0.78 & 4.61 & 0.85 & 2.44 & 0.355 & 2.36 & 0.345 & 12.9 & 0.69 \\
\hline D12 & 6.20 & 23.0 & 3.94 & 0.82 & 3.59 & 0.53 & 2.96 & 0.58 & 1.69 & 0.239 & 1.58 & 0.242 & 14.7 & 0.67 \\
\hline D13 & 7.04 & 25.8 & 5.00 & 1.16 & 4.09 & 0.61 & 3.88 & 0.71 & 2.08 & 0.305 & 1.97 & 0.327 & 11.3 & 0.78 \\
\hline D14 & 8.12 & 30.7 & 5.80 & 1.22 & 4.62 & 0.73 & 4.65 & 0.87 & 2.36 & 0.352 & 2.29 & 0.366 & 11.4 & 0.72 \\
\hline D15 & 9.12 & 34.1 & 6.62 & 1.33 & 5.65 & 0.86 & 4.93 & 0.97 & 2.77 & 0.415 & 2.84 & 0.432 & 9.9 & 0.66 \\
\hline D16 & 8.84 & 33.7 & 6.48 & 1.29 & 5.42 & 0.83 & 4.95 & 0.92 & 2.83 & 0.391 & 2.57 & 0.383 & 10.6 & 0.67 \\
\hline D17 & 8.22 & 29.9 & 6.10 & 1.23 & 5.13 & 0.80 & 4.54 & 0.88 & 2.54 & 0.356 & 2.20 & 0.342 & 11.5 & 0.67 \\
\hline D18 & 8.21 & 30.3 & 6.77 & 1.28 & 5.06 & 0.76 & 4.57 & 0.93 & 2.68 & 0.382 & 2.29 & 0.380 & 11.2 & 0.67 \\
\hline D19 & 7.51 & 28.9 & 5.63 & 1.18 & 4.49 & 0.69 & 4.03 & 0.77 & 2.22 & 0.324 & 2.24 & 0.326 & 10.8 & 0.72 \\
\hline D20 & 6.81 & 25.4 & 4.85 & 1.03 & 3.77 & 0.66 & 3.85 & 0.71 & 1.95 & 0.290 & 1.94 & 0.292 & 11.3 & 0.74 \\
\hline D21 & 9.91 & 34.9 & 5.54 & 1.33 & 4.43 & 0.69 & 4.36 & 0.77 & 2.23 & 0.301 & 2.02 & 0.324 & 14.9 & 0.82 \\
\hline D22 & 9.08 & 33.1 & 6.13 & 1.31 & 5.04 & 0.77 & 4.56 & 0.88 & 2.33 & 0.364 & 2.39 & 0.348 & 12.4 & 0.72 \\
\hline D23 & 7.37 & 26.5 & 5.36 & 1.12 & 4.07 & 0.67 & 4.10 & 0.83 & 2.37 & 0.355 & 2.10 & 0.302 & 11.9 & 0.73 \\
\hline D24 & 8.18 & 29.9 & 5.77 & 1.23 & 4.45 & 0.72 & 4.25 & 0.81 & 2.45 & 0.345 & 2.16 & 0.316 & 12.0 & 0.74 \\
\hline D25 & 9.22 & 34.7 & 7.39 & 1.30 & 5.50 & 0.87 & 5.12 & 1.01 & 2.75 & 0.399 & 2.54 & 0.384 & 11.3 & 0.62 \\
\hline Average & 8.19 & 30.3 & 5.84 & 1.21 & 4.71 & 0.73 & 4.34 & 0.83 & 2.39 & 0.347 & 2.26 & 0.340 & 11.6 & 0.71 \\
\hline
\end{tabular}

${ }^{1}$ Limit of detection (ppm). ${ }^{2}$ Values calculated from chondrite-normalized concentration. Chondrite values by Boynton (1984).

gypsum contents are attributed to atmospheric reactions. The major element compositions of Asian dust also coincided with those of Mongolian Gobi Desert soils (Fig. 6).

Geochemical properties of Asian dust and Mongolian Gobi Desert soils were compared with those of Taklamakan Desert soils from previous works (Honda and Shimizu, 1998; Honda et al., 2004; Jiang and Yang, 2019). The low Al, $\mathrm{Fe}$, and $\mathrm{K}$ concentrations of the Taklamakan Desert soils indicated low clay mineral contents compared with those of Asian dust and Gobi Desert soils, whereas the high Ca concentration indicated the enrichment of calcite in the Taklamakan Desert soils (Fig. 6). The chemical index of alteration (CIA; Nesbitt and Young, 1982) was calculated using silicate $\mathrm{CaO}$ (Tables 3, S2), and is shown in the $\mathrm{A}-\mathrm{CN}-\mathrm{K}$ diagram (Fig. 11a). The range of CIA values for Asian dust was consistent with the range for Gobi Desert soils but could be clearly distinguished from that of Taklamakan Desert soils (Fig. 11a). This indicated the enrichment of illitic clay minerals in Asian dust and Gobi Desert soils derived from clayrich bedrock. Th-Sc-La and $\mathrm{Th}-\mathrm{Sc}-\mathrm{Zr} / 10$ discrimination diagrams by Bhatia and Crook (1986) showed that both the Asian dust and Gobi Desert soils were majorly derived from the source rocks formed in the tectonic setting of the continental island arc, whereas the Taklamakan Desert soils were majorly derived from the source rocks in the setting of the passive margin (Fig. 11b, c). The Cs/K-Cs/Rb plot showed the discrimination of Taklamakan Desert soils from both the Asian dust and Gobi Desert soils (Fig. 11d). Since Cs is almost partitioned into illitic clay minerals (Derkowski and McCarty, 2017), fine fractions of Mongolian Gobi Desert soils were enriched in illitic clay minerals relative to those of the Taklamakan Desert. The properties of major and trace element compositions suggested that the Taklamakan Desert was not the source of Asian dust observed in Korea. There is some limitation due to the differences in the size fractions of the samples analyzed by investigators. Nevertheless, the geochemical data of the $<20 \mu \mathrm{m}$ fraction in the Mongolian Gobi Desert soils were consistent with those of the $<63 \mu \mathrm{m}$ fractions in this study (Fig. S3).

\subsection{Path dependence of Asian dust geochemistry}

The large temporal variation in $\mathrm{Ca}$ contents is a prominent feature of Asian dust, in contrast to the small variations in $\mathrm{Fe}$, Ti, K, Al, and Si contents (Fig. 9). Mg and Na contents also 


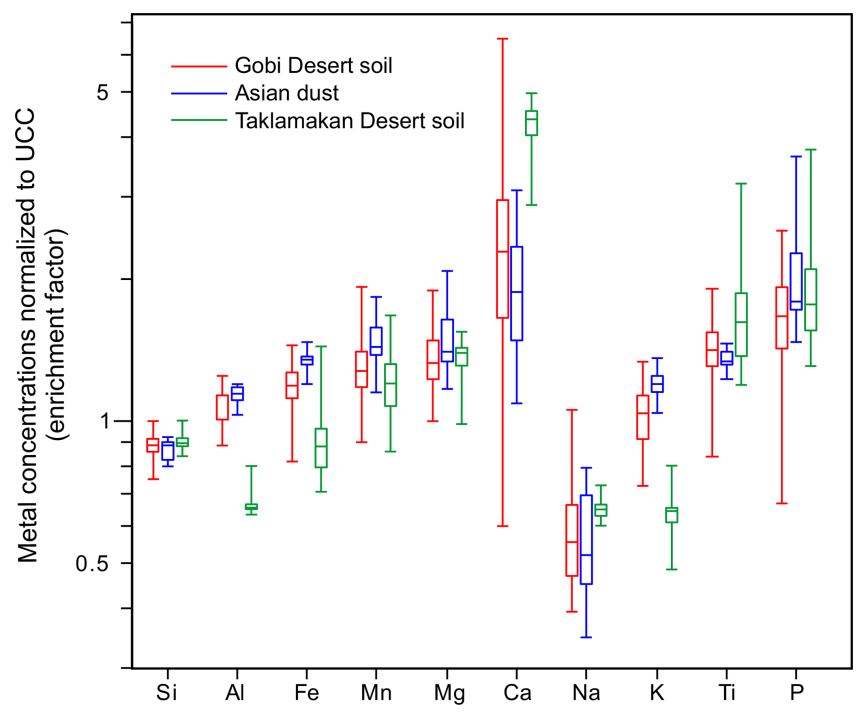

Figure 6. Box and whiskers plot comparing the major element compositions between Asian dust and source soil samples normalized to the average values of the upper continental crust (UCC) by Rudnick and Gao (2003). Data for the Taklamakan Desert soils are from Honda et al. (1998; < $45 \mu \mathrm{m})$ and Jiang and Yang $(2019 ;<63 \mu \mathrm{m})$.

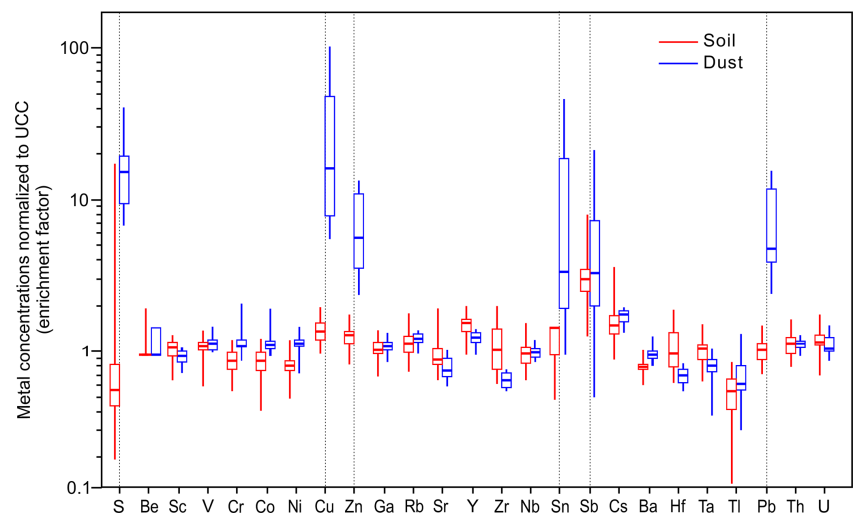

Figure 7. Box and whiskers plot comparing the trace element compositions between Asian dust and source soil samples, normalized to the average values of the UCC.

varied significantly and showed positive correlations with the Ca content (Figs. 9, S4). Migration path data of the individual dust event in Fig. S1 showed that the Ca content is associated with the migration path of Asian dust. In total, $40 \%$ of the Asian dust storms migrating to the Korean Peninsula crossed the Chinese Loess Plateau (D3-6, D7, D10-11, D12, D1920, and D21-23 in Fig. 9). All of the dust storms passing over the Loess Plateau were enriched with $\mathrm{Ca}$ (enrichment factor $>2.0$ in Fig. 9).

Potential origins of the high-Ca dust storms are proposed here. The first is the entrainment of dust particles from the Loess Plateau. Although most dust storms originate from the deserts northwest of Loess Plateau, the storms may contin-

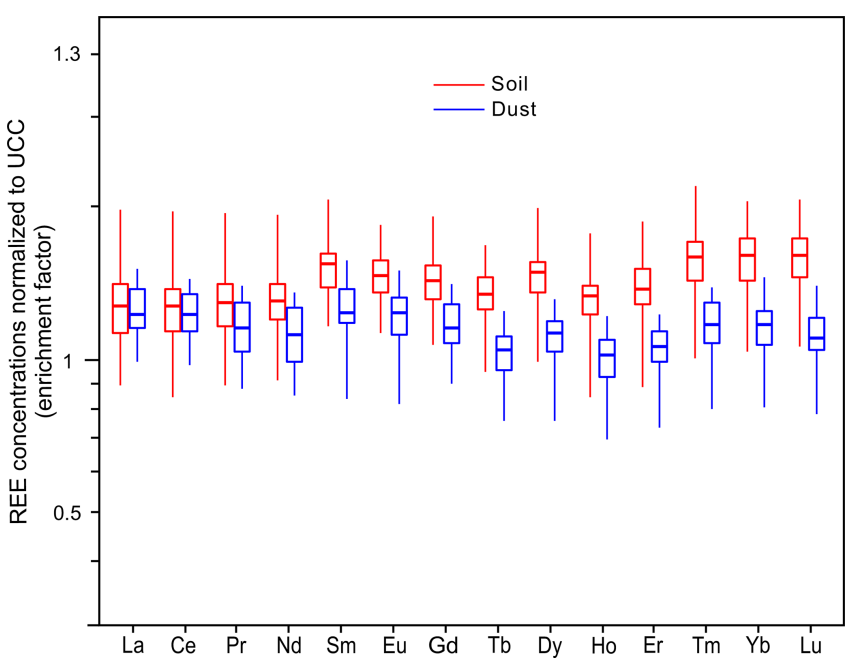

Figure 8. Box and whiskers plot comparing the rare earth element (REE) compositions between Asian dust and source soil samples, normalized to the average values of the UCC.

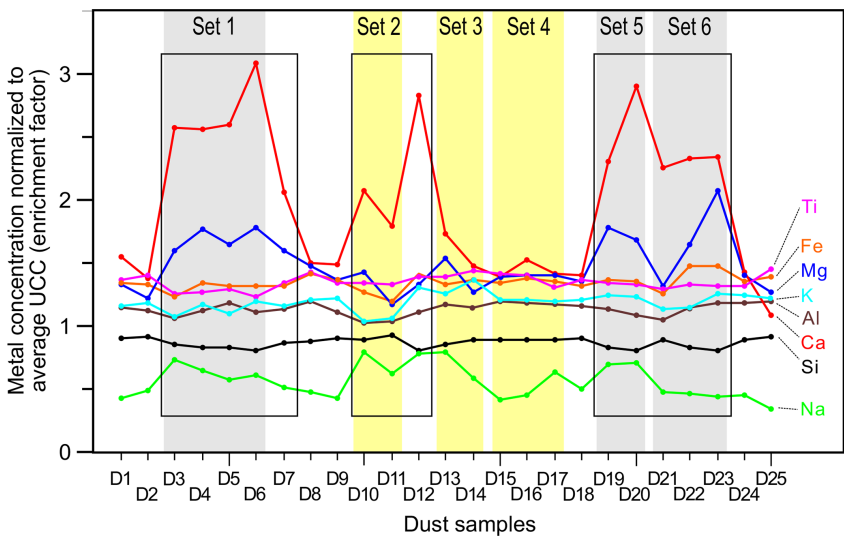

Figure 9. Time-series of variation in major element compositions of Asian dust normalized to the average values of the UCC. Dusts in the square boxes (D3-D7, D10-D12, and D19-D23) were transported across the Chinese Loess Plateau and sandy deserts in northern China (Fig. S1). Sample collection dates are provided in Table 1. Dust sample sets 1,5 , and 6 are serial samples collected during individual dust events. Dust sample sets $2-4$ are samples collected at different sites during individual dust events.

uously entrain fine particles from the Loess Plateau in their early stages, i.e., just after leaving the desert. Loess is a loose eolian sediment comprising fine silt particles and is probably susceptible to wind erosion. The average UCC-normalized $\mathrm{Ca}$ content of the source soil samples (Table S2), excluding three outliers (G2, G19, and G28), was 2.2 versus $2.7-2.9$ for loess (Jeong et al., 2008, 2011). Abundant pedogenic calcite was derived via the dissolution of primary calcite in climates wetter than desert (Jeong et al., 2008, 2011). In addition, the satellite image showed a dust outbreak over the Loess Plateau in 2013 (D12; Fig. S1). However, the mass emission of dust 


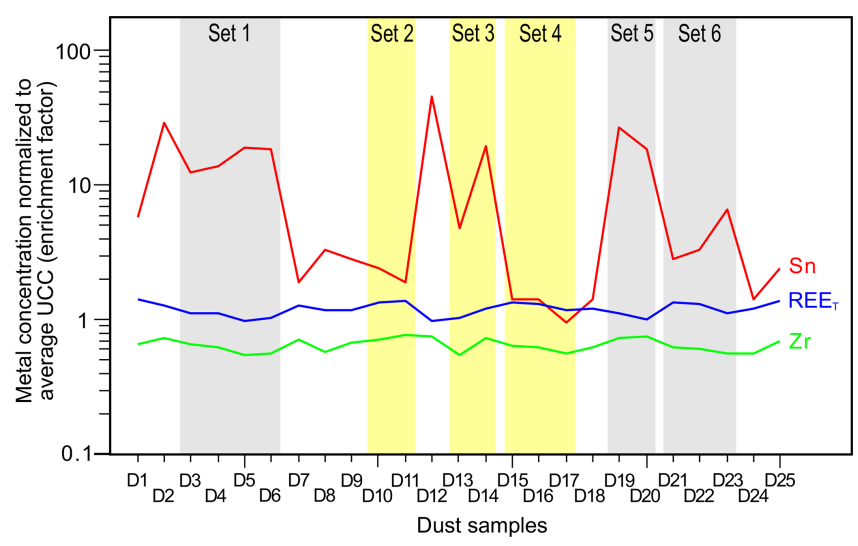

Figure 10. Time-series variation in trace element compositions of Asian dust normalized to the average values of the UCC.

particles from the Loess Plateau is contradictory to current understanding. Most observation and dust emission modeling data has shown that the Chinese Loess Plateau is a major sink for dust, but it is a very minor source (Zhang et al., 2003; Xuan et al., 2004).

The second potential origin of high-Ca dust storms is the sandy deserts of northern China, which are distributed between the Mongolian Gobi Desert and the Loess Plateau. The mineralogy and geochemistry of the fine soil fractions of the Mongolian Gobi Desert (Tables S1-S3) and the Loess Plateau (Table S4) have been well characterized in this study and in previous work (Jahn et al., 2001). However, the fine soil fractions of the sandy deserts lying between the Gobi Desert and the Loess Plateau were not investigated in this study and have rarely been addressed in previous works. The Gobi Desert ranges from southern Mongolia to northern China and is covered with silt, sand, gravel, rocky outcrops, and sparse vegetation with scattered dunes; in contrast, the sandy deserts in northern China (Badain Jaran, Tengger, Wulanbuhe, Kubuqi, and Maowusu deserts) are covered with dune fields. Subsaline to hypersaline and dry lakes are particularly common in the interdune basin of the Badain Jaran and Tengger deserts (Yang et al., 2003, 2011). Na, Ca, and Mg are the major cations in the hypersaline lake waters. Calcareous cementation is common on the surfaces of paleodunes. Calcareous lacustrine sediments deposited when the lake level was high are distributed around lakes and dry basins (Yang et al., 2003). Calcareous cements and deposits composed of soft carbonate minerals are vulnerable to sand blasting occurring during dust storms, which supplies calcareous dust to migrating storms. A fraction of $\mathrm{Mg}$ and $\mathrm{Na}$ may also be present in the form of carbonates. In this study, XRD analyses of the samples from dust events that passed over the Loess Plateau revealed a weak peak corresponding to natron $\left(\mathrm{Na}_{2} \mathrm{CO}_{3} \times 10 \mathrm{H}_{2} \mathrm{O}\right)$. The role of the sandy desert of northern China in the major element composition of Asian dust merits further investigation.
At this stage of research, the origin of high-Ca dust storms cannot be fully resolved because analytical data are insufficient, particularly in the sandy deserts of northern China. The origin of high-Ca dust could be clarified by further mineralogical and geochemical investigation of the sandy deserts and estimation of the possibility of dust emission from the Loess Plateau.

\subsection{Fractionation of minerals in dust}

The mineral compositions of the dust samples were generally consistent with those of source soils, indicating that little mineralogical fractionation occurred during dust storm outbreak and migration. It is noted that the coarsest dust (D11) was enriched with quartz and feldspars but relatively depleted in clay minerals. The dust samples for one individual event (set 6; see Fig. 4) showed systematic changes in mineral contents, i.e., increasing clay mineral content and decreasing quartz and feldspar contents, toward the end of the dust event. The temporal changes in the mineralogy of the set 6 samples (D21-23) appear to be attributable to a decrease in particle size. The size distribution curves in Fig. 2 show the gradual decrease in the coarse fractions $(>10 \mu \mathrm{m})$ from D21 to D23. In the samples of sets 1 and 5, temporal changes in the mineral composition were not evident and were difficult to explain. These may be related to the meteorological conditions during storm outbreak, migration, gravity settling, mixing, or cloud processing. Mineral compositions of dust collected at different sites during individual events (sample sets 2-4; see Fig. 4) showed no obvious differences among sites, indicating that the Korean Peninsula is likely too narrow to exhibit spatial variation in the Asian dust properties.

\subsection{Fractionation of trace elements between soils and dust}

The ranges of the major element contents of the Asian dust samples were consistent with those of source soils, whereas trace elements in the dust were fractionated from soils, showing lower Y, Zr, Hf, Ta, and heavy REE contents (Figs. 7, 8). Preferential depletion of heavy REEs suggests depletion of zircon, which is a mineral known to host heavy REEs (Henderson, 1984). Gravity settling of trace heavy minerals, particularly zircon, during the migration may be responsible for the fractionation of trace elements between soil and dust.

The chondrite-normalized $(\mathrm{La} / \mathrm{Yb})_{\mathrm{N}}$ ratio (chondrite values by Boynton, 1984) represents the fractionation of heavy REEs from light REEs. The average $(\mathrm{La} / \mathrm{Yb})_{\mathrm{N}}$ ratio of Asian dust in this study was 11.6 , which was considerably higher than that of the source soil samples (8.7), and was probably due to the depletion of heavy REE-rich zircon. Meanwhile, the average europium (Eu) anomaly of dust $(0.71)$ was not different from that of soil (0.70), which showed little fractionation (Tables 4, S3) because Eu is hosted by plagioclase. The Chinese Loess Plateau is a sink of Asian dust neighbor- 


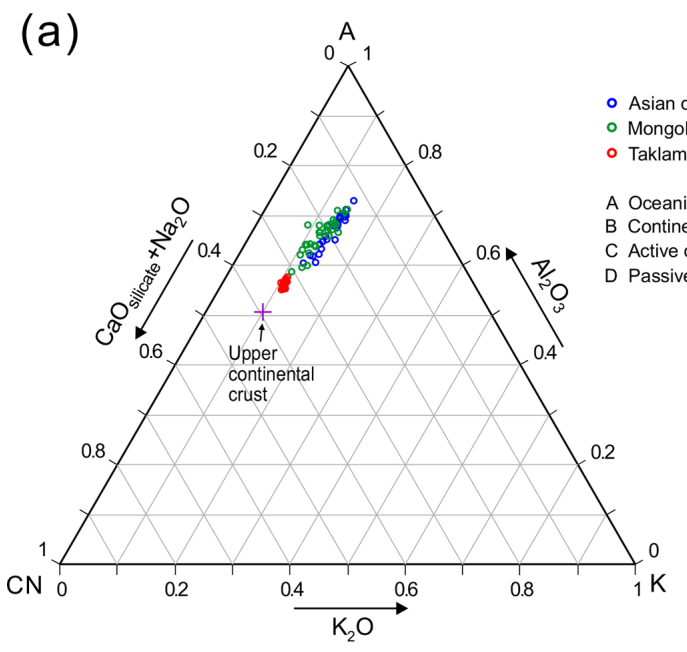

(c)

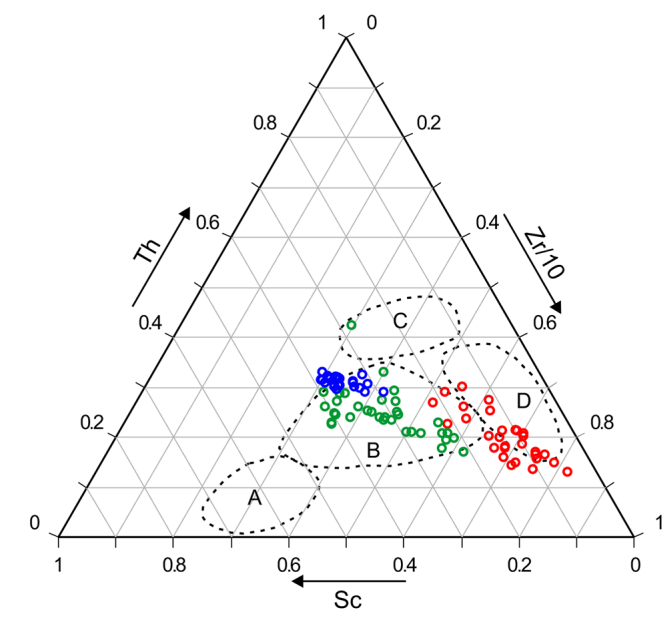

(b)

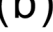

Asian dust

- Mongolian Gobi Desert

Taklamakan Desert

Oceanic island arc A Actinental island arc

Passive margin

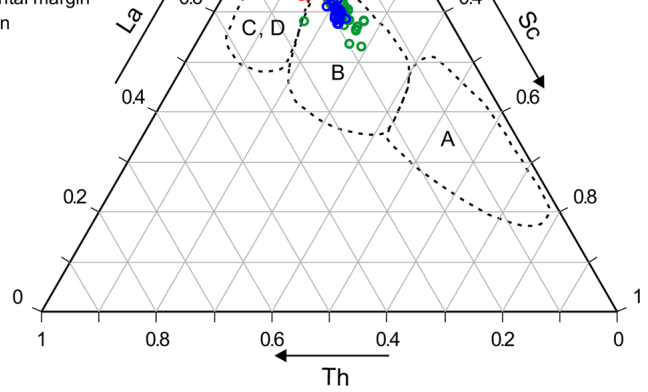

(d)

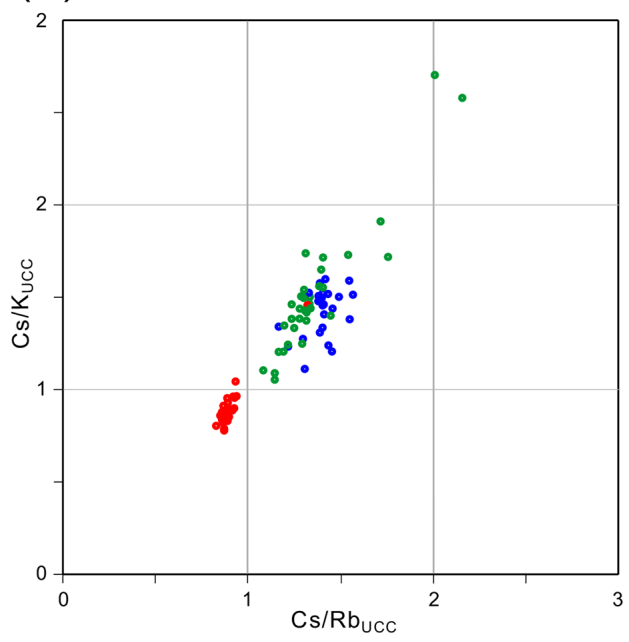

Figure 11. Plots of trace and major element compositions for discriminating the source of Asian dust. (a) A-CN-K diagram showing the molecular proportions of $\mathrm{Al}_{2} \mathrm{O}_{3}, \mathrm{~K}_{2} \mathrm{O}$, and $\mathrm{CaO}_{\text {silicate }}+\mathrm{Na}_{2} \mathrm{O}$. The value of $\mathrm{Al}_{2} \mathrm{O}_{3}$ is equivalent to the CIA. CaO $\mathrm{O}_{\text {silicate }}$ was obtained by the correction of carbonate $\mathrm{CaO}$ (Honda and Shimizu, 1998). (b) La-Th-Sc plot. (c) Th-Sc-Zr/10 plot. (d) Cs/KUCC $-\mathrm{Cs} / \mathrm{Rb}$ UCC plot. Data were normalized to UCC. Data of the Asian dust and Mongolian Gobi Desert soils $(<20 \mu \mathrm{m})$ are from this study. Trace element data for Taklamakan Desert soils are from Jiang and Yang $(2019 ;<63 \mu \mathrm{m})$. Major element data for Taklamakan Desert soils are from Honda and Shimizu $(1998 ;<45 \mu \mathrm{m})$ and Jiang and Yang $(2019 ;<63 \mu \mathrm{m})$.

ing on deserts. The $(\mathrm{La} / \mathrm{Yb})_{\mathrm{N}}$ ratio of Chinese loess is 8.7 in this study (average for 44 samples; Table S4) and 9.0 in Jahn et al. (2001; average for 30 samples; Table S5). The $\mathrm{Eu}$ anomaly for the Chinese loess showed little fractionation (0.65 in this study, and 0.64 in Jahn et al., 2001) from soils (0.70). These data indicate that Asian dust deposited on the Loess Plateau neighboring on the dust source experienced little fractionation.

Analytical data of REE compositions are rare to find in previous works on Asian dust transported over long distances. Lee et al. (2010) measured REEs in Asian dust sampled at three sites, derived from a dust event that took place in Korea during the period from 24 to 25 April 2006. The average $(\mathrm{La} / \mathrm{Yb})_{\mathrm{N}}$ and $\mathrm{Eu} / \mathrm{Eu}^{*}$ ratios recalculated based on their REE data were 11.5 and 0.55 , respectively (Table S6). The $(\mathrm{La} / \mathrm{Yb})_{\mathrm{N}}$ ratio obtained by Lee et al. (2010) is consistent with the values obtained in this study, although the Eu anomaly is somewhat low. The REE contents of Asian dust that originated from the Gobi Desert and was transported to the St. Elias Mountains (Yukon Territory, Canada) were reported by Zdanowicz et al. (2007). The $(\mathrm{La} / \mathrm{Yb})_{\mathrm{N}}$ and $\mathrm{Eu} / \mathrm{Eu}^{*}$ ratios calculated based on the six REE data in the Yukon dust (excluding local dust) are 11.1 and 0.65, respectively (Table S6), which are consistent with those for Korean dust. These findings support that the geochemical and mineralogical characteristics of Asian dust sampled in the Yukon Territory were not very different from the dust sampled in Korea. Remarkably, the modal volume diameters of Asian 
dust particles are uniform among samples collected at the western margin of the North Pacific (this study), in North Pacific Ocean sediments (Serno et al., 2014), and in the subarctic mountains of the North America (Zdanowicz et al., 2007). Previous studies have shown that dust did not show significant changes in size distribution beyond a transport distance of $\sim 2000 \mathrm{~km}$, (Nakai et al., 1993; Rea, 1994; Rea and Hovan, 1995; Serno et al., 2014). Rather uniform properties of trans-Pacific Asian dust indicate that REE fractionation of Asian dust occurred within a distance of $\sim 2000 \mathrm{~km}$ from sources.

Deep-sea sediment samples from the central North Pacific Ocean were investigated in terms of REE contents to elucidate paleoclimatic changes. Since the sediments are normally mixtures of local volcanogenic particles and longrange transported eolian dust from Asia, Chinese loess (and related sediments) is usually selected as an end-member of the eolian component to estimate the accumulation rate and provenance of eolian particles. The $(\mathrm{La} / \mathrm{Yb})_{\mathrm{N}}$ ratios of Asian dust fractions separated from pelagic sediments from the North Pacific were recorded as 9.1 (three central North Pacific samples, Nakai et al., 1993), 7.3 (11 samples from a southern transect, Serno et al., 2014), and 7.7 (type 1 samples, Hyeong et al., 2004) (Tables S7). These values are much lower than those of the Asian dust transported long distances in Zdanowicz et al. (2007), Lee et al. (2010), and this study. The Eu anomaly of pelagic sediments (0.66, Nakai et al. 2004; 0.74, Hyeong et al. 2004; 0.73, Serno et al. 2014; Table S7) is similar to that of Asian dust (0.71, this study; 0.65, Zdanowicz et al., 2007). REE data on long-range transport Asian dust in this study may improve the usefulness of REE as a proxy of paleoclimatic change.

\subsection{Mixing and reaction of Asian dust with polluted air}

Asian dust passes through industrialized regions of East Asia, where air pollution is a severe environmental issue. Asian dust mixes and reacts with polluted air (Nishikawa et al., 1991; McKendry, et al., 2008; Huang et al., 2010). The concentration of atmospheric pollutants is high, particularly in winter and spring seasons which are also the major seasons of dust outbreaks. Calcite, which is the most reactive mineral in dust, reacts with acidic gases in the atmosphere (mostly sulfur species) originating from pollution (Dentener et al., 1996; Laskin et al., 2005; Matsuki et al., 2005; Jeong and Chun, 2006; Takahashi et al., 2009, 2014). The higher gypsum and lower calcite contents of Asian dust compared with source soils (Tables 2, S1, and Fig. 5) suggest the conversion of calcite into gypsum during transport (Takahashi et al., 2009, 2014). This conversion is also supported by the similar average $\mathrm{Ca}$ contents of both the dust $(5.1 \%)$ and soils $(6.4 \%)$. During one of the individual dust events in this study (set 6 samples; see Fig. 4), the increased gypsum content and concomitantly decreased calcite content were clearly the result of the progressive reaction of dust with air pollutants toward the end of the dust event. During the dust event of set 3 , the gypsum content of dust was greatly enhanced concomitantly with the decrease in the calcite content on Deokjeok Island (D14), whereas it was lower than the calcite content at Andong (D13). This supports the conversion of calcite to gypsum in the severely polluted atmosphere around the densely populated metropolitan region of Seoul, Korea. Marked variation in both the calcite $(0.5 \%-11 \%)$ and gypsum $(0 \%-18 \%)$ contents of dust is intuitive because pollutant concentrations vary widely with regional weather conditions.

In Asian dust, $\mathrm{Cu}, \mathrm{Zn}, \mathrm{Sn}$, and $\mathrm{Pb}$ (Fig. 7) are the major heavy metal pollutants of combustion origin (Duan and Tan, 2013). Although the contents of $\mathrm{Cu}, \mathrm{Zn}$, and $\mathrm{Pb}$ were not analyzed in all of the samples due to small dust quantities, the marked temporal variation in the Sn content represent the temporal variation in heavy metal pollutants (Fig. 10). The intra-event dust samples of set 6 showed a gradual increase in the Sn content toward the end of the dust event, whereas the contents of REEs and $\mathrm{Zr}$ of soil origin decreased progressively, consistent with progressive mixing of dust with regional pollutants (Fig. 10). The Sn content was low in samples of sets 2 and 4, showing only minor variations, but it was high in D14 (set 3) on Deokjeok Island, consistent with high gypsum content.

\section{Summary and conclusions}

Systematic analyses of Asian dust samples collected over a long period showed mineralogical and geochemical properties consistent with those of the fine silt fractions $(<20 \mu \mathrm{m})$ of the source soils. Clay minerals were most abundant, followed by quartz, plagioclase, K-feldspar, calcite, and gypsum. Asian dust crossing the Loess Plateau has a higher $\mathrm{Ca}$ content, entraining calcite-rich fine dust particles that probably originated from calcareous sediments in northern Chinese sandy deserts and pedogenic calcite-rich loess. Dustladen air parcels mix with atmospheric pollutants over East Asia. Calcite was found to react with pollutants to form gypsum. Serial dust samples for each dust event show scant changes in major element contents. However, trace element contents varied widely due to REE fractionation and mixing with polluted air enriched with heavy metals of pollution origin. The selective depletion of heavy REEs in dust from source soils resulted in increased $(\mathrm{La} / \mathrm{Yb})_{\mathrm{N}}$ ratios. The samples of one dust event showed a trend of increasing clay minerals and gypsum contents toward the end of the event in association with decreasing particle size and progressive reactions. Mineral dust transported over long distances is the subject of much interdisciplinary research. This study describes not only the average properties of dust but also interevent variations therein and fractionation from source soils, thereby providing a basis for climatic and atmospheric re- 
action modeling and for the analysis of deep-sea sediments, fine-grained soils, and ice sheet dust.

Data availability. All underlying research data are available in the Supplement to this article.

Supplement. The supplement related to this article is available online at: https://doi.org/10.5194/acp-20-7411-2020-supplement.

Competing interests. The author declares that there are no conflicts of interest.

Acknowledgements. The author is grateful to Chang-Sik Cheong for providing important suggestions on an early draft of the paper. The author also wishes to thank Konrad Kandler and the anonymous reviewer for their detailed and constructive comments.

Financial support. This research has been supported by the National Research Foundation of Korea (grant no. NRF2017R1A2B2011422).

Review statement. This paper was edited by Ryan Sullivan and reviewed by Konrad Kandler and one anonymous referee.

\section{References}

An, Z. S., Kukla, G., and Porter, S. C.: Magnetic susceptibility evidence of Monsoon variation on the loess plateau of central China during the last 130000 years, Quaternary Res., 36, 29-36, 1991.

Bautista-Tulin, A. T. and Inoue, K.: Hydroxy-interlayered minerals in Japanese soils influenced by eolian deposition, Soil Sci. Soc. Am. J., 61, 631-640, 1997.

Bhatia, M. R. and Crook, A. A. W.: Trace element characteristics of graywackes and tectonic setting discrimination of sedimentary basins, Contrib. Mineral. Petrol., 92, 181-193, 1986.

Biscaye, P. E., Grousset, F. E., Revel, M., Van der Gaast, S., Zielinski, G. A., Vaars, A., and Kukla, G.: Asian provenance of glacial dust (stage 2) in the Greenland Ice Sheet Project 2 Ice Core, Summit, Greenland, J. Geophys. Res., 102, 26765-26781, 1997.

Bory, A. J.-M., Biscaye, P. E., Svensson, A., and Grousset, F. E.: Seasonal variability in the origin of recent atmospheric mineral dust at North GRIP, Greenland, Earth Planet Sc. Lett., 196, 123134, 2002.

Boynton, W. V.: Geochemistry of the rare earth elements: meteorite studies: Rare Earth Element Geochemistry, edited by: Henderson, P., Elsevier, printed in Netherlands, 510 pp., 1984.

Chen, J., Li, G., Yang, J., Rao, W., Lu, J., Balsam, W., Sun, Y., and $\mathrm{Ji}, \mathrm{J} .: \mathrm{Nd}$ and $\mathrm{Sr}$ isotopic characteristics of Chinese deserts: implications for the provenances of Asian dust, Geochim. Cosmochim. Ac., 71, 3904-3914, 2007.
Chun, Y., Boo, K. -O., Kim, J., Park, S.-U., and Lee, M.: Synopsis, transport, and physical characteristics of Asian dust in Korea, J. Geophys. Res.-Atmos., 106, 18461-18469, 2001.

Dentener, F. J., Carmichael, G. R., Zhang, Y., Lelieveld, J., and Crutzen, P. J.: Role of mineral aerosol as a reactive surface in the global troposphere, J. Geophys. Res., 101, 22869-22889, 1996.

Derkowski, A. and McCarty, D. K.: Cesium, a water-incompatible, siloxane-complexed cation in Earth's upper crust, Geology, 45, 899-902, https://doi.org/10.1130/G39150.1, 2017.

Duan, J. and Tan, J.: Atmospheric heavy metals and Arsenic in China: Situation, sources and control policies, Atmos. Environ., 74, 93-101, 2013.

Ferrat, M., Weiss, D. J., Strekopytov, S., Dong, S. F., Chen, H. Y., Najorka, J., Sun, Y. B., Gupta, S., Tada, R., and Sinha, R.: Improved provenance tracing of Asian dust sources using rare earth elements and selected trace elements for palaeomonsoon studies on the eastern Tibetan Plateau, Geochim. Cosmochim. Ac., 75, 6374-6399, 2011.

Formenti, P., Schütz, L., Balkanski, Y., Desboeufs, K., Ebert, M., Kandler, K., Petzold, A., Scheuvens, D., Weinbruch, S., and Zhang, D.: Recent progress in understanding physical and chemical properties of African and Asian mineral dust, Atmos. Chem. Phys., 11, 8231-8256, https://doi.org/10.5194/acp11-8231-2011, 2011.

Forster, P., Ramaswamy, V., Artaxo, P., Berntsen, T., Betts, R., Fahey, D. W., Haywood, J., Lean, J., Lowe, D. C., Myhre, G., Nganga, J., Prinn, R., Raga, G., Schulz, M., and Van Dorland, R.: Changes in Atmospheric Constituents and in Radiative Forcing, in: Climate Change 2007: The Physical Science Basis, Contribution of Working Group I to the Fourth Assessment Report of the Intergovernmental Panel on Climate Change, edited by: Solomon, S., Qin, D., Manning, M., Chen, Z., Marquis, M., Averyt, K. B., Tignor, M., and Miller, H. L., Cambridge University Press, printed in United Kingdom, 940 pp., 2007.

Henderson, P.: General geochemical properties and abundances of the rare earth elements: Rare Earth Element Geochemistry, edited by: Henderson, P., Elsevier, printed in Netherlands, 510 pp., 1984.

Honda, M. and Shimizu, H.: Geochemical, mineralogical and sedimentological studies on the Taklimakan Desert sands, Sedimentology, 45, 1125-1143, 1998.

Honda, M., Yabuki, S., and Shimizu, H.: Geochemical and isotopic studies of Aeolian sediments in China, Sedimentology, 51, 211230, 2004.

Huang, K., Zhuang, G., Li, J., Wang, Q., Sun, Y., Lin, Y., and $\mathrm{Fu}$, J. S.: Mixing of Asian dust with pollution aerosol and the transformation of aerosol components during the dust storm over China in spring 2007, J. Geophys. Res., 115, D00K13, https://doi.org/10.1029/2009JD013145, 2010.

Husar, R. B., Tratt, D. M., Schichtel, B. A., Falke, S. R., Li, F., Jaffe, D., Gassó, S., Gill, T., Laulainen, N. S., Lu, F., Reheis, M. C., Chun, Y., Westphal, D., Holben, B. N., Gueymard, C., McKendry, I., Kuring, N., Feldman, G. C., McClain, C., Frouin, R. J., Merrill, J., DuBois, D., Vignola, F., Murayama, T., Nickovic, S., Wilson, W. E., Sassen, K., Sugimoto, N., and Malm, W. C.: Asian dust events of April 1998, J. Geophys. Res.-Atmos., 106, 18317-18330, 2001.

Hyeong, K., Park, S.-H., Yoo, C. M., and Kim, K.-H.: Mineralogical and geochemical compositions of the eolian dust from the 
northeast equatorial Pacific and their implications on paleolocation of the Intertropical Convergence Zone, Paleoceanography, 20, PA1010, https://doi.org/10.1029/2004PA001053, 2005.

Jahn, B. M., Gallet, S., and Han, J. M.: Geochemistry of the Xining, Xifeng and Jixian sections, Loess Plateau of China: eolian dust provenance and paleosol evolution during the last $140 \mathrm{ka}$, Chem. Geol., 178, 71-94, 2001.

Jiang, Q. and Yang, X.: Sedimentological and geochemical composition of aeolian sediments in the Taklamakan Desert: implications for provenance and sediment supply mechanisms, J. Geophys. Res.-Ea, 124, 1217-1237, https://doi.org/10.1029/2018JF004990, 2019.

Jickells, T. D., An, Z. S., Andersen, K. K., Baker, A. R., Bergametti, G., Brooks, N., Cao, J. J., Boyd, P. W., Duce, R. A., Hunter, K. A., Kawahata, H., Kubilay, N., laRoche, J., Liss, P. S., Mahowald, N., Prospero, J. M., Ridgwell, A. J., Tegen, I., and Torres, R.: Global iron connections between desert, dust, ocean biogeochemistry, and climate, Science, 308, 67-71, 2005.

Jeong, G. Y.: Bulk and single-particle mineralogy of Asian dust and a comparison with its source soils, J. Geophys. Res.-Atmos., 113, D02208, https://doi.org/10.1029/2007JD008606, 2008.

Jeong, G. Y. and Chun, Y.: Nanofiber calcite in Asian dust and its atmospheric roles, Geophys. Res. Lett., 33, L24802, https://doi.org/10.1029/2006GL028280, 2006.

Jeong, G. Y. and Achterberg, E. P.: Chemistry and mineralogy of clay minerals in Asian and Saharan dusts and the implications for iron supply to the oceans, Atmos. Chem. Phys., 14, 1241512428, https://doi.org/10.5194/acp-14-12415-2014, 2014.

Jeong, G. Y. and Nousiainen, T.: TEM analysis of the internal structures and mineralogy of Asian dust particles and the implications for optical modeling, Atmos. Chem. Phys., 14, 7233-7254, https://doi.org/10.5194/acp-14-7233-2014, 2014.

Jeong, G. Y., Hillier, S., and Kemp, R. A.: Quantitative bulk and single-particle mineralogy of a thick Chinese loess-paleosol section: implications for loess provenance and weathering, Quat. Sci. Rev., 37, 1271-1287, 2008.

Jeong, G. Y., Hillier, S., and Kemp, R. A.: Changes in mineralogy of loess-paleosol sections across the Chinese Loess Plateau, Quaternary Res., 75, 245-255, 2011.

Jeong, G. Y., Choi, J. -H., Lim, H. S., Seong, C., and Yi, S. B.: Deposition and weathering of Asian dust in Paleolithic sites, Korea, Quat. Sci. Rev., 78, 283-300, 2013.

Jeong, G. Y., Kim, J. Y., Seo, J., Kim, G. M., Jin, H. C., and Chun, Y.: Long-range transport of giant particles in Asian dust identified by physical, mineralogical, and meteorological analysis, Atmos. Chem. Phys., 14, 505-521, https://doi.org/10.5194/acp-14505-2014, 2014.

Jeong, G. Y., Park, M. Y., Kandler, K., Nousiainen, T., and Kemppinen, O.: Mineralogical properties and internal structures of individual fine particles of Saharan dust, Atmos. Chem. Phys., 16, 12397-12410, https://doi.org/10.5194/acp-16-12397-2016, 2016.

Jickells, T. D., An, Z. S., Andersen, K. K., Baker, A. R., Bergametti, G., Brooks, N., Cao, J. J., Boyd, P. W., Duce, R. A., Hunter, K. A., Kawahata, H., Kubilay, N., laRoche, J., Liss, P. S., Mahowald, N., Prospero, J. M., Ridgwell, A. J., Tegen, I., and Torres, R.: Global iron connections between desert, dust, ocean biogeochemistry, and climate, Science, 308, 67-71, 2005.
Jo, H.-Y., Jeong, G. Y., and Park, M. Y.: Mineralogy, geochemistry, and eolian source of mountain soils on quartzite. J. Geol. Soc. Korea, 55, 87-103, 2019 (in Korean with English abstract).

Johnson, M. S. and Meskhidze, N.: Atmospheric dissolved iron deposition to the global oceans: effects of oxalate-promoted $\mathrm{Fe}$ dissolution, photochemical redox cycling, and dust mineralogy, Geosci. Model Dev., 6, 1137-1155, https://doi.org/10.5194/gmd6-1137-2013, 2013.

Kanayama, S., Yabuki, S., Yanagisawa, F., and Motoyama, R.: The chemical and strontium isotope composition of atmospheric aerosols over Japan: the contribution of long-range-transported Asian dust (Kosa), Atmos. Environ., 36, 5159-5175, 2002.

Korea Meteorological Administration: Portal Opening Meteorological Data, available at: https://data.kma.go.kr/cmmn/main.do, last access: 1 October 2019.

Krueger, B. J., Grassian, V. H., Cowin, J. P., and Laskin, A.: Heterogeneous chemistry of individual mineral dust particles from different dust source regions: the importance of particle mineralogy, Atmos. Environ., 38, 6253-6261, 2004.

Laskin, A., Wietsma, T. W., Krueger, B. J., and Grassian, V. H.: Heterogeneous Chemistry of Individual Mineral Dust Particles with Nitric Acid: A Combined CCSEM/EDX, ESEM, and ICP-MS Study, J. Geophys. Res.-Atmos., 110, D10208, https://doi.org/10.1029/2004JD005206, 2005.

Lee, M. K., Lee, Y. I., and Yi, H. I.: Provenances of atmospheric dust over Korea from $\mathrm{Sr}-\mathrm{Nd}$ isotopes and rare earth elements in early 2006, Atmos. Environ., 44, 2401-2414, 2010.

Leinen, M., Prospero, J. M., Arnold, E., and Blank, M.: Mineralogy of Aeolian dust reaching the North Pacific Ocean, 1. Sampling and analysis, J. Geophys. Res.-Atmos., 99, D10, 21017-21023, 1994.

Liu, T. S.: Loess in China, China Ocean Press, Springer-Verlag, printed in Germany, 224 pp., 1988.

Maher, B. A., Mutch, T. J., and Cunningham, D.: Magnetic and geochemical characteristics of Gobi Desert surface sediments: implications for provenance of the Chinese loess, Geology, 37, 279-282, 2009.

Mahowald, N. M. and Kiehl, L. M.: Mineral aerosol and cloud interaction, Geophys. Res. Lett., 30, 1475 , https://doi.org/10.1029/2002GL016762, 2003.

Martin, J. H. and Fitzwater, S. F.: Iron deficiency limits phytoplankton growth in the north-east Pacific subarctic, Nature, 331, 341342, 1988.

Matsuki. A., Iwasaka, Y., Shi, G., Zhang, D., Trochkine, D., Yamada, M., Kim, Y. -S., Chen, B., Nagatani, T., Miyazawa, T., Nagatani, M., and Nagata, H.: Morphological and chemical modification of mineral dust: Observational insight into the heterogeneous uptake of acidic gases, Geophys. Res. Lett., 32, L22806, https://doi.org/10.1029/2005GL024176, 2005.

McGee, D., Winckler, G., Borunda, A., Serno, S., Anderson, R. F., Recasens, C., Bory, A., Gaiero, D., Jaccard, S. L., Kaplan, M., McManus, J. F., Revel, M., and Sun, Y.: Tracking eolian dust with helium and thorium: Impacts of grain size and provenance, Geochim. Cosmochim. Ac., 175, 47-67, 2016.

McKendry, I. G., Macdonald, A. M., Leaitch, W. R., van Donkelaar, A., Zhang, Q., Duck, T., and Martin, R. V.: Trans-Pacific dust events observed at Whistler, British Columbia during INTEX-B, Atmos. Chem. Phys., 8, 6297-6307, https://doi.org/10.5194/acp8-6297-2008, 2008. 
Meskhidze, N., Chameides, W. L., and Nenes, A.: Dust and pollution: a recipe for enhanced ocean fertilization, J. Geophys. Res., 110, D03301, https://doi.org/10.1029/2004JD005082, 2005.

Moore, D. M. and Reynolds, R. C.: X-ray diffraction and the identification and analysis of clay minerals, Oxford University Press, printed in New York, 378 pp., 1997.

Nakai, S., Halliday, A. N., and Rea, D. K.: Provenance of dust in the Pacific Ocean, Earth Planet Sc. Lett., 119, 143-157, 1993.

National Meteorological Satellite Center: available at: http://nmsc. kma.go.kr/enhome/html/main/main.do, last access: 16 September 2019.

Nesbitt, H. W. and Young, G. M.: Early Proterozoic climates and plate motions inferred from major element chemistry of lutite, Nature, 299, 715-717, 1982.

Nishikawa, M., Kanamori, S., Kanamori, N., and Mizoguchi, T.: Kosa aerosol as eolian carrier of anthropogenic material, Sci. Total Environ., 107, 13-27, 1991.

Olivarez, A. M., Owen, R. M., and Rea, D. K.: Geochemistry of eolian dust in Pacific pelagic sediments: Implications for paleoclimatic interpretations, Geochim. Cosmochim. Ac., 55, 21472158, 1991.

Park, M. Y. and Jeong, G. Y.: Mineralogical properties of Asian dust sampled at Deokjeok Island, Incheon, Korea in February 22, 2015, J. Min. Soc. Korea, 29, 79-87, 2016 (in Korean with English abstract).

Pettke, T., Halliday, A. N., Hall, C. M., and Rea, D. K.: Dust production and deposition in Asia and the north Pacific Ocean over the past 12 Myr, Earth Planet Sc. Lett., 178, 397-413, 2000.

Porter, S. C.: Chinese loess record of monsoon climate during the last glacial-interglacial cycle, Earth-Sci. Rev., 54, 115-128, 2001.

Rea, D. K.: The paleoclimatic record provided by eolian deposition in the deep sea: the geologic history of wind, Rev. Geophys., 32, 159-195, 1994.

Rea, D. K. and Hovan, S. A.: Grain size distribution and depositional processes of the mineral component of abyssal sediments: Lessons from the North Pacific, Paleoceanography, 10, 251-258, 1995.

Rea, D. K., Snoeckx, H., and Joseph, L. H.: Late Cenozoic eolian deposition in the North Pacific: Asian drying, Tibetan uplift, cooling of the northern hemisphere, Paleoceanography, 13, 215-224, 1998.

Rudnick, R. and Gao, S.: Composition of the continental crust: The Crust, Treatise on Geochemistry, Vol. 3., edited by: Rudnick, R. L., Elsevier-Pergamon, printed in Italy, 203 pp., 2003.

Seinfeld, J. H., Carmichael, G. R., Arimoto, R., Conant, W. C., Brechtel, F. J., Bates, T. S., Cahill, T. A., Clarke, A. D., Doherty, S. J., Flatau, P. J., Huebert, B. J., Kim, J., Markowicz, K. M., Quinn, P. K., Russell, L. M., Russell, P. B., Shimizu, A., Shinozuka, Y., Song, C. H., Tang, Y., Uno, I., Vogelmann, A. M., Weber, R. J., Woo, J.-H., and Zhang, X. Y.: ACE-ASIA regional climatic and atmospheric chemical effects of Asian dust and pollution, B. Am. Meteorol. Soc., 85, 367-380, 2004.
Serno, S. S., Winckler, G., Anderson, R. F., Hayes, C. T., McGee, D., Machalett, B., Ren, H., Straub, S. M., Gersonde, R., and Haug, G. H.: Eolian dust input to the Subarctic North Pacific, Earth Planet Sc. Lett., 387, 252-263, 2014.

Shi, Z., Shao, L., Jones, T. P., and Lu, S.: Microscopy and mineralogy of airborne particles collected during severe dust storm episodes in Beijing, China, J. Geophys. Res., 110, D01303, https://doi.org/10.1029/2004JD005073, 2005.

Takahashi, Y., Higashi, M., Furukawa, T., and Mitsunobu, S.: Change of iron species and iron solubility in Asian dust during the long-range transport from western China to Japan, Atmos. Chem. Phys., 11, 11237-11252, https://doi.org/10.5194/acp-1111237-2011, 2011.

Takahashi, Y., Miyoshi, T., Higashi, M., Kamioka, H., and Kanai, Y.: Neutralization of calcite in mineral aerosols by acidic sulfur species collected in China and Japan studied by Ca K-edge Xray absorption near-edge structure, Environ. Sci. Technol., 43, 6535-6540, 2009.

Takahashi, Y., Higashi, M., Furukawa, T., Miyoshi, T., Fujiwara, M., and Uematsu, M.: A study of the chemical processes in aerosols and their impacts on the environment using X-ray absorption fine structure spectroscopy, in: Western Pacific Air-Sea Interaction Study, edited by: Uematsu, M., Yokouchi, Y., Watanabe, Y. W., Takeda, S., and Yamanaka, Y., TERRAPUB, printed in Japan, https://doi.org/10.5047/w-pass.a01.005, 2014.

Xuan, J., Sokolik, I. N., Hao, J., Guo, F., Mao, H., and Yang, G.: Identification and characterization of sources of atmospheric mineral dust in East Asia, Atmos. Environ., 38, 6239-6252, 2004.

Yang, X., Liu, T., and Xiao, H.: Evolution of megadunes and lakes in the Badain Jaran desert, Inner Mongolia, China during the last 31000 years, Quatern. Int., 104, 99-112, 2003.

Yang, X., Scuderi, L., Paillou, P., Liu, Z., Li, H., and Ren, X.: Quaternary environmental changes in the drylands of China - A critical review, Quat. Sci. Rev., 30, 3219-3233, 2011.

Zdanowicz, C., Hall, G., Vaive, J., Amelin, Y., Percival, J., Girard, I., Biscaye, P., and Bory, A.: Asian dustfall in the St. Elias Mountains, Yukon, Canada, Geochim. Cosmochim. Ac., 70, 34933507, 2007.

Zhang, X. Y., Gong, S. L., Zhao, T. L., Arimoto, R., Wang, Y. Q., and Zhou, Z. J.: Sources of Asian dust and role of climate change versus desertification in Asian dust emission, Geophys. Res., Lett., 30, 2272, https://doi.org/10.1029/2003GL018206, 2003. 